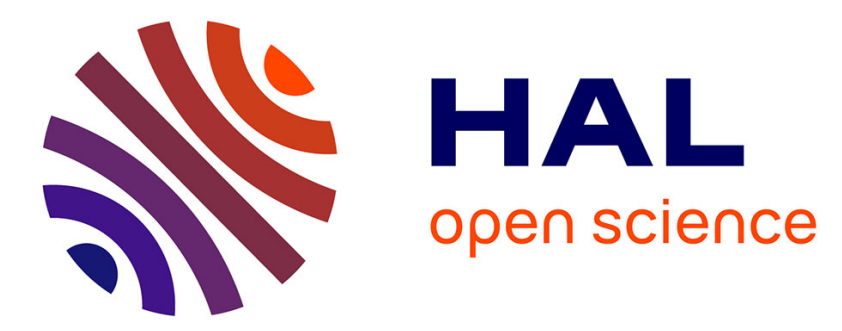

\title{
Systematic review of use and interpretation of dietary diversity indicators in nutrition- sensitive agriculture literature
}

Eric O. Verger, Terri J Ballard, Marie-Claude Dop, Yves Martin-Prével

\section{- To cite this version:}

Eric O. Verger, Terri J Ballard, Marie-Claude Dop, Yves Martin-Prével. Systematic review of use and interpretation of dietary diversity indicators in nutrition- sensitive agriculture literature. Global Food Security, 2019, 20, pp.156-169. 10.1016/j.gfs.2019.02.004 · hal-02079050

\section{HAL Id: hal-02079050 https://hal.science/hal-02079050}

Submitted on 1 Apr 2019

HAL is a multi-disciplinary open access archive for the deposit and dissemination of scientific research documents, whether they are published or not. The documents may come from teaching and research institutions in France or abroad, or from public or private research centers.
L'archive ouverte pluridisciplinaire HAL, est destinée au dépôt et à la diffusion de documents scientifiques de niveau recherche, publiés ou non, émanant des établissements d'enseignement et de recherche français ou étrangers, des laboratoires publics ou privés. 
Systematic review of use and interpretation of dietary diversity indicators in nutritionsensitive agriculture literature

\section{Author names and affiliations}

Eric O Verger ${ }^{\mathrm{a}}$, Terri J Ballard ${ }^{\mathrm{b}}$, Marie Claude Dop ${ }^{\mathrm{a}}$ and Yves Martin-Prevel ${ }^{\mathrm{a}}$

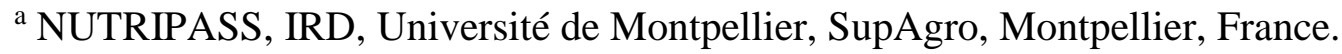

eric.verger@ird.fr ; marieclaude.dop@gmail.com ; yves.martin-prevel@ird.fr

${ }^{\mathrm{b}}$ Independent consultant, Italy

tjballard.fsn@gmail.com

\section{Corresponding author}

Eric O Verger

NUTRIPASS, IRD, Université de Montpellier, SupAgro, 911 avenue d'Agropolis, 34000

Montpellier, France

Email: eric.verger@ird.fr

Tel.: +33467416268.

\section{Funding}

This research did not receive any specific grant from funding agencies in the public, commercial, or not-for-profit sectors. 
2 In the past decade, food group dietary diversity indicators (FGIs) have increasingly been used to assess the impact of agriculture on food security or nutrition. Following a structured search strategy and a two-phase screening process, 46 studies investigating associations between agriculture and food security or nutrition through the use of simple FGIs were assessed for how the indicators were constructed and interpreted. Most studies based on individual level FGIs

7 were consistent with published guidance, while many of the studies measuring households' dietary diversity were not, particularly in terms of interpretation of the indicators or of food group classification. Efforts are needed to harmonize the way FGIs are used and interpreted in order to enhance comparability across studies and allow meta-analyses of the association between agriculture and food security or nutrition.

\section{Graphical abstract}

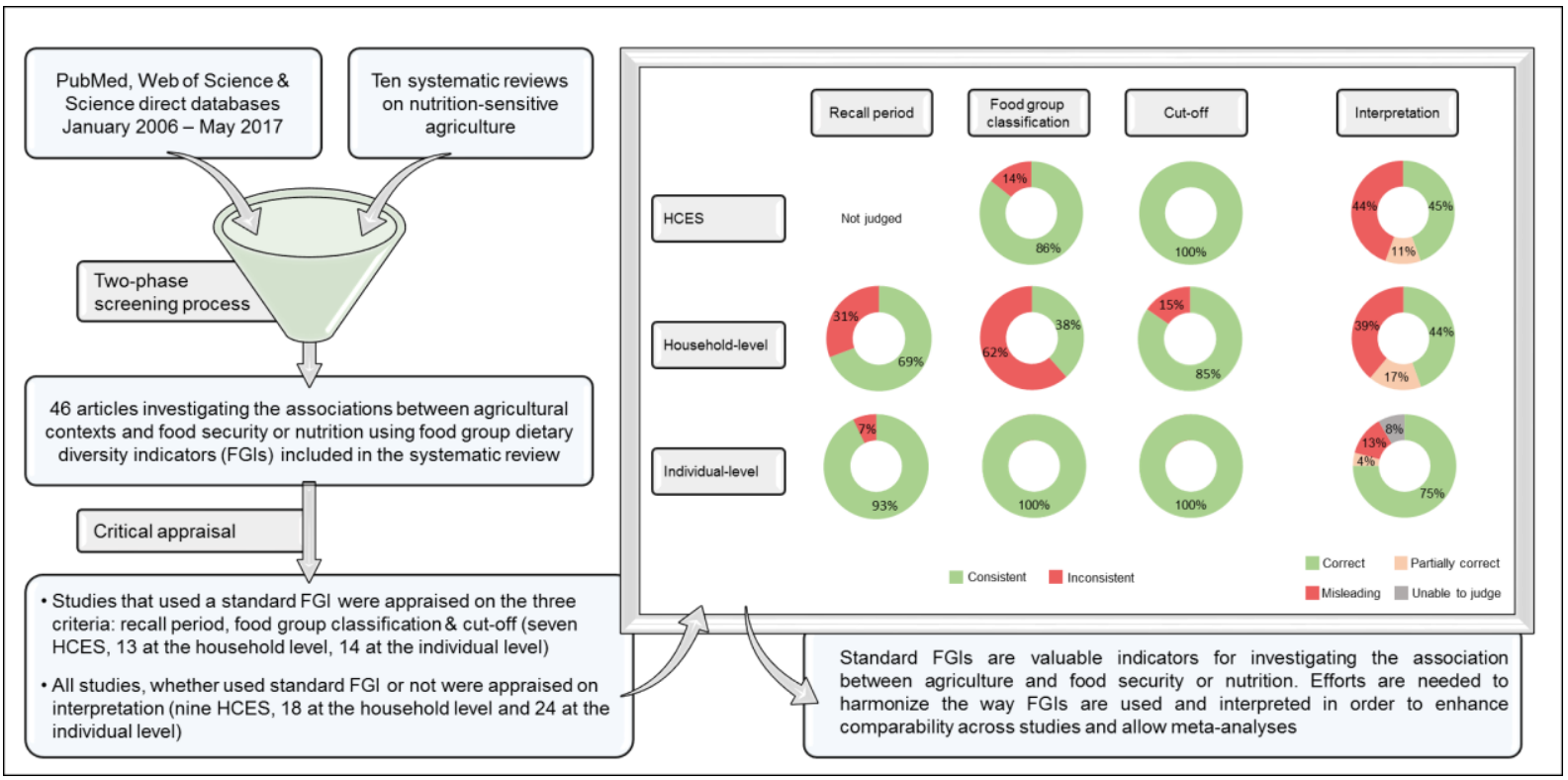

Keywords

17 Dietary diversity; nutrition; food security; agricultural practices; agricultural contexts; critical appraisal. 


\section{Introduction}

Pathways through which agriculture can improve nutrition are complex (World Bank, 2007). Conceptual frameworks elaborated to describe impact pathways from agriculture to nutrition (Kadiyala et al., 2014) follow the model of the "conceptual framework for the analysis of the causes of malnutrition", which orders causes as immediate, underlying or basic determinants of malnutrition (UNICEF, 1990). According to this framework, agriculture, as a basic determinant, impacts nutrition through underlying determinants that include access to food, care practices and health environment. In turn, underlying determinants impact nutritional status through two immediate determinants - food intake and health.

The choice of indicators in studies of the nutritional impact of agricultural interventions and programmes is a crucial issue (Webb and Kennedy, 2014). Many studies use nutritional status as the principal impact indicator, as pointed out by several authors (Masset et al., 2012; Girard et al., 2012; Pandey et al., 2016). Several reviews of relevant studies have shown little evidence of an impact on child anthropometric status, partly due to methodological limitations (Masset et al., 2012; Ruel and Alderman, 2013; Gillespie and van den Bold, 2017). This lack of evidence may be due to the multifactorial nature of nutritional status, its low sensitivity to change and to large sample requirements for detecting an impact when there is one. In a review of on-going agriculture-nutrition intervention projects, Herforth and Ballard (2016) found that almost all were using dietary indicators for assessing impact on nutrition, an important shift in focus compared to the previous decade when anthropometry was considered the only outcome of interest.

Dietary indicators are more specific and sensitive to change in food availability and access than nutritional status and require smaller samples (Herforth and Ballard, 2016). However, assessing diets is a challenging endeavour. Quantitative dietary intake assessments are cumbersome and 
require highly specialized skills. To address this issue, several simple proxy dietary indicators have been developed, among which the most widely used are indicators of dietary diversity. It has been recognized that dietary diversity, a key component of diet quality, helps to ensure intake of essential nutrients (Ruel, 2003). Monotonous diets are associated with multiple nutrient deficiencies. Dietary diversity is a holistic feature of the diet in contrast with intake of single nutrients. Moreover dietary diversity is a key feature of food-based dietary guidelines (WHO, 1996).

Simple food group indicators (FGIs) assess whether people consume foods from specific food groups, defined as a set of foods that share similar nutritional properties or biological characteristics (Arimond et al., 2010). Four FGIs, developed to reflect dietary diversity of households or individuals, have been validated against multi-site quantitative food intake datasets in order to operationalize the measurement of dietary diversity at population level. They are proxies of access to a variety of foods in the field of food security (at household level) or of nutrient adequacy of the diet, one key dimension of diet quality (at individual level) (Ruel, 2003).

At the household level, a 10-country analysis showed an association between an FGI and per capita energy availability (Hoddinott and Yohannes, 2002). The Household Dietary Diversity Score (HDDS), constructed by counting the number of food groups consumed by the household over the previous 24 hours, was proposed as an indicator of the access dimension of food security. Guidelines were published to standardize the implementation of a 12-food group indicator (Swindale and Bilinsky, 2006). At the individual level, simple indicators were developed for monitoring progress in feeding practices for infants and young children. Ten datasets were used to identify indicators correlated with the mean adequacy of the micronutrient density of complementary foods across nine micronutrients. As a result, a dichotomous indicator of Minimum Dietary Diversity (MDD) of four or more food groups, out of seven, 
consumed over the previous 24 hours was validated for infants and young children six to 23 months old (Working Group on Infant and Young Child Feeding Indicators, 2006). Guidelines for standardizing the implementation of the MDD were published by the World Health Organization (WHO, 2008, 2010). In parallel, a dietary diversity indicator was developed to reflect the mean probability of adequacy of women's diets across 11 micronutrients. Several dietary diversity scores were validated using five datasets (Arimond et al., 2010). Guidelines were published that promoted a simple nine food group dietary diversity score for women of reproductive age, the Women's Dietary Diversity Score (WDDS) (FAO, 2011). This was followed by an analysis of nine datasets to create and validate the Minimum Dietary Diversity for Women of Reproductive Age (MDD-W), a dichotomous indicator of five or more food groups, out of 10, consumed over the previous 24 hours (Women's Dietary Diversity Project Study Group, 2017). FAO and FHI360 (2016) published a guidance manual.

The HDDS, MDD, WDDS and MDD-W have undergone extensive validation work, using datasets from multiple sites, to arrive at proxy indicators of diet that are approximately comparable in meaning across different contexts and over time. Their characteristics are described in Table 1. These indicators require far fewer skills than quantitative intake surveys for data collection, analysis and interpretation. They are based on a qualitative 24-hour recall, which is less prone to bias and recall error than other methods, and results of assessments are simpler to analyse (NIH-NCI, 2018). Because of their relative simplicity and demonstrated validity, these four standard FGIs have been widely used by researchers from different sectors, in particular in studies of the impact of agriculture on food security and nutrition (Herforth and Ballard, 2016). This paper reviews published studies that investigated the association between agricultural practices or agricultural contexts and food security or nutrition by using simple FGIs of dietary diversity. The purpose of the review is to assess to what extent and how studies used and interpreted common metrics of dietary diversity, which would improve comparability 
across studies to produce global evidence of the impact of agriculture on nutrition and food security. We acknowledge however that not all studies have an objective of comparisons across settings. The intent of the review was not to judge the validity of the studies or their results.

\section{Methods}

\subsection{Selection of studies for the review}

Systematic reviews of research on nutrition-sensitive agriculture were examined to identify key terms and the most relevant scientific literature databases for carrying out the search (Balagamwala and Gazdar, 2013; Dury et al., 2015; Fiorella et al., 2016; Kadiyala et al., 2014; Masset et al., 2012; Pandey et al., 2016; Penafiel et al., 2011; Powell et al., 2015; Warren et al., 2015; Webb and Kennedy, 2014). Based on this first step, a structured search strategy was developed to include terms related to dietary diversity and agricultural practices or contexts ${ }^{1}$, spanning publications from 2006 up to 23 May 2017. This search strategy was applied to three databases: PubMed, Web of Science and Science direct. Additionally, reference lists of recent systematic reviews on nutrition-sensitive agriculture and of studies included in this review were examined to identify other potentially relevant studies. The search was limited to peer-reviewed articles published in English. All populations and study designs were eligible for inclusion, from cross-sectional studies to randomized controlled trials or other impact evaluation designs.

\footnotetext{
1 (“diet* diversity") AND (household* OR family OR woman OR women OR child* OR infant*) AND ("agricultur* intervention" OR "agricultur* program" OR "agricultur* growth" OR "home* food production" OR "farm* production" OR "household production" OR "crop production" OR "biomass production" OR "farm productivity" OR "agricultur* productivity" OR "food crop*" OR "cash crop*" OR "cash-cropping" OR "commercial agriculture" OR "farming contract" OR "agricultur* diversity" OR "production diversity" OR "crop diversity" OR "crop diversification" OR "product diversification" OR "biodiversity" OR "agrobiodiversity" OR "agro-biodiversity" OR "agricultural intensification" OR "aquaculture" OR "agriculture-aquaculture" OR "fisher*" OR "fishing" OR "livestock ownership" OR "livestock rearing" OR "bio-fortification" OR "biofortification" OR "irrigation" OR “women's empowerment" OR "seed" OR "intercropping” OR "land-use"). For the PubMed search, the terms were not truncated.
} 
All studies identified from the initial search strategy were filed and handled using Zotero (version 4.0.28.7). A two-stage screening process was employed to select the final studies to be reviewed. At each stage, the first author screened and reviewed all studies, which were also divided among the three co-authors for a simultaneous review. All disagreements regarding eligibility were resolved through discussion.

At the first stage, all titles and abstracts were examined. Studies that were obviously irrelevant, such as those not investigating associations between any type of agricultural practice or context and food security or nutrition, ecological studies or papers discussing the associations theoretically or conceptually only, as well as reviews or meta-analyses, were excluded from further review. The studies selected at the first stage underwent a full-text screen against the second stage inclusion criterion: only studies that investigated associations between agricultural practices or contexts and food security or nutrition and that used FGIs.

To facilitate the second stage full-text screening, the following information was tabulated using a standardized data extraction form: (i) location of the study (e.g. country); (ii) study design (e.g. cross-sectional study); (iii) subjects and sample size; (iv) purpose of the study; (v) name and reference of the dietary diversity indicator used; (vi) recall period (period of time for which food group consumption is reported, e.g. previous day or previous week); (vii) food group classification; (viii) use of a cut-off; and (ix) interpretation of the dietary diversity indicator. Reasons for exclusion of studies after the second stage full-text screening included investigations of non-specific agricultural practices or contexts, such as forest cover, proximity to marine protected areas or merely rural residence, and those that did not actually measure diversity of the diet using an FGI.

\subsection{Critical appraisal}


Following the two screening stages, each of the remaining studies was critically appraised for use and interpretation of FGIs. First, studies were categorized by whether they measured dietary diversity at the household level, individual level or both. The studies were then categorized by whether they used a standard FGI, i.e. HDDS, MDD, WDDS, or MDD-W. Those that did use a standard FGI were assessed for consistency with the published guidance based on three criteria: 1) recall period, 2) food group classification and 3) use or not of a cut-off for creating a categorical indicator. Studies that did not use a standard FGI were excluded from the appraisal for these three criteria. For the remaining that did use a standard FGI, the recall period was judged as "consistent" if the study used a 24-hour recall, otherwise "inconsistent". Studies using secondary data from Household Consumption and Expenditure Surveys (HCES) to construct an FGI were excluded from assessment of this criterion because HCES systematically use longer recall periods. The food group classification was judged as "consistent" if the study used the recommended number of food groups and food group definitions, otherwise "inconsistent". The use of a cut-off was judged as "consistent" if the recommended thresholds for the MDD and MDD-W were used, if no ad hoc cut-off was applied to the HDDS or the WDDS since these two indicators do not have recommended thresholds, or if cut points based on a quantile distribution of the dietary diversity score were applied to the HDDS or WDDS. This element was judged as "inconsistent" if other cut-off approaches were used or were not used when appropriate to do so.

The full set of studies, including those that did not use one of the four standard indicators, was assessed on how the FGI employed was interpreted in relation to the level of analysis. The interpretation of the FGI was judged as "correct" if consistent with the level at which it was applied (e.g. interpretation in terms of access to a variety of foods in the field of food security for household measures and in terms of nutrient adequacy of the diet, one key dimension of diet quality, for individual measures). The interpretation was judged as "misleading" if it was not 
consistent with the objective of the study and level of analysis. An intermediate judgment of "partially correct" was assigned when the interpretation of the results was consistent with the level of analysis, thus correct, but either the indicator was not strictly appropriate for the research question or the investigators interpreted a household level indicator as a measurement of nutrition or diet quality in the introduction or discussion section of the paper.

All disagreements among reviewing co-authors regarding the critical assessment were resolved through discussion.

\section{Results}

\subsection{Description of the studies}

As presented in Figure 1, the first stage of the systematic review identified 155 published studies. Of these, 97 were judged as clearly irrelevant at the first stage and were excluded. In addition to the remaining 58 included in the second stage, nine others were identified from reference lists of the included studies and were added for a total of 67 eligible studies for full text screening. Of these, 11 were subsequently eliminated because they did not specifically use an FGI, two because they did not investigate agricultural practices or contexts, and eight because there was no quantification of the association between agricultural practice or context and FGI. Forty-six studies were thus selected for the final review.

Overall, there was a wide heterogeneity across the 46 studies regarding the unit of analysis, the location, study design, sample size, choice of indicators and analysis of the dietary diversity data (see Appendices A, B and C for a complete list of reviewed studies). Five studies measured dietary diversity at both the household and individual level, 19 only at the individual level, and 22 only at the household level, of which nine from HCES secondary analyses. Sixteen studies 
reported dietary diversity of children; nine of those included children older than 23 months (range 24-83 months).

Data from 30 different countries were reported across the 46 studies: 14 from Africa, nine from Asia, five from Latin America, and two from Eastern Europe; 16 countries were reported on only once and 14 were reported on in more than one study. Malawi was the most frequently included country, reported on in nine studies. Three of the nine studies using HCES pooled data from multiple countries, ranging from four to 15 .

Forty of the 46 studies used a cross-sectional design, five reported on impact evaluation and only one used a longitudinal design. Sample sizes greatly varied from as small as 30 to over 10,000 (papers conducting multi-country secondary analyses of national HCES).

\subsection{Critical appraisal of the use and interpretation of FGIs}

Table 2 lists the results of the assessment based on the four criteria, shown separately for studies using HCES data, other household level data and individual level data (see Appendices A, B and $\mathrm{C}$ for detailed description of the reviewed studies).

\subsubsection{Critical appraisal of the use of standard FGIs}

Thirty of the 46 studies made reference to standard indicators (HDDS, MDD, WDDS or MDDW) for measuring dietary diversity and were included in the critical assessment for the three criteria pertaining to recall period, food group classification and use of a cut-point.

With respect to recall period, nine out of 13 household level studies (excluding HCES studies, which were not judged on recall period) and 13 out of 14 individual level studies used a 24hour recall period. 
Of the studies using one of the four standard FGIs, five out of seven HCES, six out of 13 household level studies and all 14 individual level studies constructed the FGI according to the recommended food group classification. The main reason for being rated "inconsistent" for food group classification was using an HDDS indicator with more or fewer food groups than the recommended 12 food groups.

With respect to the use of a score-based cut-off, all seven HCES, 11 out of 13 household level and all 14 individual level indicators were consistent with published guidance. The cases rated "inconsistent" either set their own thresholds that were not based on quantiles (for HDDS or WDDS) or did not use the established thresholds for MDD or MDD-W.

\subsubsection{Critical appraisal of the interpretation of FGIs}

With respect to interpretation of the FGI, of the nine HCES studies, four were judged as correct, one as partially correct and four as misleading. Of the 18 household level studies, eight were judged as correct, three as partially correct and seven as misleading. Of the 24 individual level studies, 18 were judged as correct, one as partially correct, three as misleading and two as "unable to judge" (See Appendices A, B and C for more details).

The reason for the interpretation of the FGI being rated as "misleading" was a mismatch between study objective, level of analysis and interpretation. This rating was given to studies that a) specifically interpreted a household level FGI applied to households as a measure of "household diet quality", "household nutrition or nutritional status", or "food and nutrition security”; or b) applied an individual FGI indicator to individuals and interpreted results as a measure of either household food security/food access or of household dietary diversity.

A study was rated as "partially correct" when the investigators made a correct interpretation for 
they used. In particular, this rating was given to studies that a) applied a standard household

232 FGI to individuals to assess nutrient adequacy of individuals, or b) applied an individual FGI at household level to assess household food security/food access, or c) made statements in the introduction or discussion section of the paper that household FGIs were measures of nutrition or diet quality even when they correctly interpreted results according to the level of analysis in the results section.

\section{Discussion}

This systematic review was undertaken to assess how dietary diversity indicators used in studies investigating the association between agricultural practices or contexts and food security or nutrition were constructed and interpreted. To our knowledge, ours is the first review of this kind. For the large majority of individual level indicators, construction and interpretation were correct. Most studies based on HCES used the HDDS correctly regarding food group classification; however, interpretation was misleading in approximately half of the cases. For the other household level studies, a majority of which used the HDDS, less than half used the recommended food group classification. Similarly, less than half applied the correct interpretation.

\subsection{Adherence to published guidance on standard FGIs}

The review highlighted several areas where use of the standard, validated FGIs was inconsistent with accepted guidance: recall period, food group definitions and number, and use of a cutpoint. In these cases, the inconsistencies may have been due to intentionally adapting the standard FGIs to the context-specific objectives of the studies. 
The recommended recall period for the four standard FGIs is the previous 24 hours. While using a different recall period might have internal relevance within a study for reasons pertaining to the specific objective or context, it limits comparability with other studies based on standard FGIs. When longer recall periods are used, higher dietary diversity scores are expected (Drewnowski et al, 1997; Arimond and Ruel, 2004a), and established cut-points of MDD and MDD-W, validated for 24-hour intake recall, no longer apply.

Food group classifications of the standard FGIs differ according to the level of analysis: household or individual. The HDDS includes both nutrient-rich and non-nutrient-rich food groups accessed by the household, and does not provide information on nutrient intakes of individual household members. In contrast, the individual level FGIs, which were designed to reflect the nutritional quality of individual diets, include only micronutrient-rich food groups. Use of nonstandard food groups or different numbers of food groups with respect to standard indicators precludes comparability with other studies and may compromise interpretation of the dietary diversity measure.

\subsection{Dietary diversity compiled from HCES consumption modules}

Secondary analyses of HCES data is a valuable source for investigating dietary outcomes of agricultural practices. HCES are conducted in a large number of countries every two to ten years, enabling the analysis of trends over time. In the past two decades, data from HCES have increasingly been used in an effort to derive food and nutrition information for policy decisions (Fiedler et al., 2013; Coates et al., 2017; Moltedo et al., 2018).

Including HCES studies investigating links between agriculture and nutrition in this review has highlighted a particular set of issues in relation to both recall period and food group composition. Three of the nine HCES studies pooled data from multiple surveys to create a 
common FGI from the survey-specific food lists for comparison across the different datasets. However, heterogeneity of the number of food items listed in survey-specific food consumption modules (ranging from 20 to 135 food items in the reviewed studies using HCES) is problematic because foods representative of important food groups, such as vegetables and fruits, may be missing when the number of food items is small. This lack of comprehensiveness of food items making up the food groups for measuring dietary diversity across datasets limits comparability and could affect interpretation of the results (Murphy et al., 2012). One study analysed dietary diversity from pooled HCES data with different recall periods (ranging from seven to 365 days). Problems with non-comparability of food lists and recall periods of food consumption modules across HCES have been documented by the International Household Survey Network in a large review (Smith et al., 2014). There is ongoing work to standardize food consumption modules in HCES, and a dietary diversity indicator for household data has been proposed by FAO (Moltedo et al., 2018), which should improve comparability across HCES in the future.

\subsection{Age/sex population groups not represented in standard FGIs}

Many of the reviewed studies measured dietary diversity on populations groups for which the standard indicators were not validated. To date, the MDD and MDD-W have been validated only for children aged six to 23 months and women of reproductive age (15-49 years), respectively. Nine studies used an FGI for children older than 23 months. MDD was developed to reflect adequacy of the micronutrient density of complementary foods of children aged six to 23 months, and thus is not appropriate to reflect the micronutrient adequacy of diets of children older than 23 months. A recent study showed that MDD-W performed better than MDD for predicting micronutrient adequacy among rural Zambian children 4 to 8 years of age (Caswell et al., 2018). Similarly, another recent study established that, using the MDD-W among pregnant women in Bangladesh, a cut-point of 6 or more food groups performed better 
than the cut-point of 5 or more food groups recommended for non-pregnant women (Nguyen et al., 2018).

Dietary diversity indicators have been found to be positively correlated with the macro and/or micronutrient adequacy of diets of children aged five to 11 years (Steyn et al., 2014), adolescents (Mirmiran et al., 2004) or elderly subjects (Rathnayake et al., 2012; Tavakoli et al., 2016) but there are no internationally validated indicators of dietary diversity currently available for these age and sex groups. There is a need for multi-site validation studies for indicators covering other age and sex groups.

\subsection{Interpretation of the dietary diversity indicators}

In more than half of the articles using HCES data or other household level data, the investigators interpreted the FGI as measures of "household nutrition", "nutrient adequacy of household diets", "household food and nutrition security", or "dietary quality". The term "nutrition" refers to the nutritional status of individuals, their nutrient requirements and their diets, not to households. Because nutrient requirements differ according to age and sex, and allocation of food between individuals in a household depends on many factors, "household nutrition" and "nutrient adequacy or quality of household diets" are inappropriate concepts.

\subsection{Strengths and limitations}

A strength of this review is the categorization of the studies in three groups (HCES, other household level and individual level) which ensures a pertinent assessment for each group. Another strength is the consistent use of two or more independent screeners to reduce errors in data extraction, as recommended by Buscemi et al. (2006). A limitation is that the review included only articles published in English. 


\section{Conclusion}

329 Our critical assessment of the use of FGIs in the selected studies revealed several issues in the way dietary diversity indicators were constructed or interpreted. Consequently, based on this systematic review, we propose a checklist of items that authors could consider and report on to ensure a consistent use and correct interpretation of dietary diversity indicators (Box1). In addition we make the following recommendations:

- Investigators using a dietary diversity indicator that is not standard but suits their purpose (such as focus on certain foods with more disaggregated food groups) should

FGIs are valuable indicators for investigating the association between agricultural practices or agricultural contexts and food security or nutrition, and their use by research and development communities is an encouraging sign. Two recent publications reviewed the literature on links between diversity of production and dietary diversity in smallholder households (Jones, 2017b; Sibhatu and Qaim, 2018). However, further reviews and meta-analyses would greatly benefit from better efforts to harmonize the way FGIs are used and interpreted in order to enhance the comparability of studies. This will be an important contribution towards building a robust body of evidence of the impact of agriculture on nutrition and food security at global level. 
Anderman, T.L., Remans, R., Wood, S.A., DeRosa, K., DeFries, R.S., 2014. Synergies and tradeoffs between cash crop production and food security: a case study in rural Ghana. Food Secur. 6, 541-554. https://doi.org/10.1007/s12571-014-0360-6.

Arimond, M., Ruel, M.T., 2004a. Dietary Diversity, Dietary Quality, and Child Nutritional Status: Evidence from Eleven Demographic and Health Surveys. Food and Nutrition Technical Assistance (FANTA) Project. Academy for Educational Development (AED), Washington, D.C.

Arimond, M., Ruel, M.T., 2004b. Dietary diversity is associated with child nutritional status: evidence from 11 demographic and health surveys. J. Nutr. 134, 2579-2585.

Arimond, M., Wiesmann, D., Becquey, E., Carriquiry, A., Daniels, M.C., Deitchler, M., Fanou-Fogny, N., Joseph, M.L., Kennedy, G., Martin-Prevel, Y., Torheim, L.E., 2010. Simple food group diversity indicators predict micronutrient adequacy of women's diets in 5 diverse, resource-poor settings. J. Nutr. 140 2059S-69S. https://doi.org/10.3945/jn.110.123414.

Balagamwala, M., Gazdar, H., 2013. Agriculture and Nutrition in Pakistan: Pathways and Disconnects1. IDS Bull. 44, 66-74. https://doi.org/10.1111/1759-5436.12032.

Bellon, M.R., Ntandou-Bouzitou, G.D., Caracciolo, F., 2016. On-Farm Diversity and Market Participation Are Positively Associated with Dietary Diversity of Rural Mothers in Southern Benin, West Africa. PLoS One 11 e0162535. https://doi.org/10.1371/journal.pone.0162535.

Benson, T., 2015. Association between irrigated farming and improved nutrition in farm households in Malawi. Agrekon 54, 62-86. https://doi.org/10.1080/03031853.2015.1084940.

Beyene, M., Worku, A.G., Wassie, M.M., 2015. Dietary diversity, meal frequency and associated factors among infant and young children in Northwest Ethiopia: a crosssectional study. BMC Public Health 15, 1007. https://doi.org/10.1186/s12889-152333-X.

Buscemi, N., Hartling, L., Vandermeer, B., Tjosvold, L., Klassen, T.P., 2006. Single data extraction generated more errors than double data extraction in systematic reviews. J. Clin. Epidemiol. 59, 697-703. https://doi.org/10.1016/j.jclinepi.2005.11.010.

Cabalda, A.B., Rayco-Solon, P., Solon, J.A.A., Solon, F.S., 2011. Home gardening is associated with Filipino preschool children's dietary diversity. J. Am. Diet Assoc. 111, 711-715. https://doi.org/10.1016/j.jada.2011.02.005.

Caswell, B.L., Talegawkar, S.A., Siamusantu, W., West, K.P., Palmer, A.C., 2018. A 10-Food Group Dietary Diversity Score Outperforms a 7-Food Group Score in Characterizing Seasonal Variability and Micronutrient Adequacy in Rural Zambian Children. J. Nutr. 148, 131-139. https://doi.org/10.1093/jn/nxx011.

Chagomoka, T., Drescher, A., Glaser, R., Marschner, B., Schlesinger, J., Nyandoro, G., 2017. Contribution of urban and periurban agriculture to household food and nutrition security along the urban-rural continuum in Ouagadougou, Burkina Faso. Renew. Agric. Food Syst. 32, 5-20. https://doi.org/10.1017/S1742170515000484.

Coates, J., Rogers, B.L., Blau, A., Lauer, J., Roba, A., 2017. Filling a dietary data gap? Validation of the adult male equivalent method of estimating individual nutrient 
intakes from household-level data in Ethiopia and Bangladesh. Food Policy 72, 27-42. https://doi.org/10.1016/j.foodpol.2017.08.010.

Dangura, D., Gebremedhin, S., 2017. Dietary diversity and associated factors among children 6-23 months of age in Gorche district, Southern Ethiopia: Cross-sectional study. BMC Pediatr. 17, 6. https://doi.org/10.1186/s12887-016-0764-X.

Daniels, M., Ballard, T., 2014. Meeting to reach consensus on a global dietary diversity indicator for women, July 2014: Summary Report; 2014.

Darling, E.S., 2014. Assessing the Effect of Marine Reserves on Household Food Security in Kenyan Coral Reef Fishing Communities. PLoS One 9. https://doi.org/10.1371/journal.pone.0113614.

Darrouzet-Nardi, A.F., Miller, L.C., Joshi, N., Mahato, S., Lohani, M., Rogers, B.L., 2016. Child dietary quality in rural Nepal: Effectiveness of a community-level development intervention. Food Policy 61, 185-197. https://doi.org/10.1016/j.foodpol.2016.03.007.

De Brauw, A., Eozenou, P., Moursi, M., 2015. Programme Participation Intensity and Children's Nutritional Status: Evidence from a Randomised Control Trial in Mozambique. J. Dev. Stud. 51, 996-1015. https://doi.org/10.1080/00220388.2015.1018907.

Dillon, A., McGee, K., Oseni, G., 2015. Agricultural Production, Dietary Diversity and Climate Variability. J. Dev. Stud. 51, 976-995. https://doi.org/10.1080/00220388.2015.1018902.

Drewnowski, A., Henderson, S.A., Driscoll, A., Rolls, B.J., 1997. The Dietary Variety Score: assessing diet quality in healthy young and older adults. J. Am. Diet Assoc. 97, 266271.

Dulal, B., Mundy, G., Sawal, R., Rana, P.P., Cunningham, K., 2017. Homestead Food Production and Maternal and Child Dietary Diversity in Nepal: Variations in Association by Season and Agroecological Zone. Food Nutr. Bull 379572117703264. https://doi.org/10.1177/0379572117703264.

Dury, S., Alpha, A., Bichard, A., 2015. The Negative Side of the Agricultural-Nutrition Impact Pathways: A Literature Review. World Food Policy 2. https://doi.org/10.18278/wfp.2.1.5.

Euler, M., Krishna, V., Schwarze, S., Siregar, H., Qaim, M., 2017. Oil Palm Adoption, Household Welfare, and Nutrition Among Smallholder Farmers in Indonesia. World Dev. 93, 219-235. https://doi.org/10.1016/j.worlddev.2016.12.019.

Fiedler, J.L., 2013. Towards overcoming the food consumption information gap: Strengthening household consumption and expenditures surveys for food and nutrition policymaking. Glob. Food Secur. 2, 56-63. https://doi.org/10.1016/j.gfs.2012.09.002.

Food and Agriculture Organization, 2008. Guidelines for measuring household and individual dietary diversity. Food and Agriculture Organization of the United Nations, Rome.

Food and Agriculture Organization, 2011. Guidelines for measuring household and individual dietary diversity. Food and Agriculture Organization of the United Nations, Rome.

FAO and FHI 360, 2016. Minimum Dietary Diversity for Women: A Guide for Measurement. FAO, Rome. 
Fiorella, K.J., Chen, R.L., Milner, E.M., Fernald, L.C.H., 2016. Agricultural interventions for improved nutrition: A review of livelihood and environmental dimensions. Glob. Food Secur. 8, 39-47. https://doi.org/10.1016/j.gfs.2016.03.003.

Gallaher, C.M., Kerr, J.M., Njenga, M., Karanja, N.K., WinklerPrins, A.M.G.A., 2013. Urban agriculture, social capital, and food security in the Kibera slums of Nairobi, Kenya. Agric. Hum. Val. 30, 389-404. https://doi.org/10.1007/s10460-013-9425-y.

Gillespie, S., van den Bold, M., 2017. Agriculture, Food Systems, and Nutrition: Meeting the Challenge. Global Challenges 1, 1600002. https://doi.org/10.1002/gch2.201600002.

Girard, A.W., Self, J.L., McAuliffe, C., Olude, O., 2012. The effects of household food production strategies on the health and nutrition outcomes of women and young children: a systematic review. Paediatr. Perinat. Epidemiol. 26 (Suppl. 1), 205-222. https://doi.org/10.1111/j.1365-3016.2012.01282.x.

Herforth, A., Ballard, T.J., 2016. Nutrition indicators in agriculture projects: Current measurement, priorities, and gaps. Glob. Food Secur. 10, 1-10. https://doi.org/10.1016/j.gfs.2016.07.004.

Hirvonen, K., Hoddinott, J., 2016. Agricultural production and children's diets: evidence from rural Ethiopia. Agric. Econ. 48, 469-480. https://doi.org/10.1111/agec.12348.

Hoddinott, J., Yohannes, Y., 2002. Dietary diversity as a food security indicator. FCND Discussion Paper No. 136.

Iannotti, L., Lesorogol, C., 2014. Dietary Intakes and Microntrient Adequacy Related to the Changing Livelihoods of Two Pastoralist Communities in Samburu, Kenya. Curr. Anthropol. 55, 475-482. https://doi.org/10.1086/677107.

Jodlowski, M., Winter-Nelson, A., Baylis, K., Goldsmith, P.D., 2016. Milk in the Data: Food Security Impacts from a Livestock Field Experiment in Zambia. World Dev. 77, 99114. https://doi.org/10.1016/j.worlddev.2015.08.009.

Jones, A.D., 2017a. On-Farm Crop Species Richness Is Associated with Household Diet Diversity and Quality in Subsistence- and Market-Oriented Farming Households in Malawi. J. Nutr. 147, 86-96. https://doi.org/10.3945/jn.116.235879.

Jones, A.D., 2017b. Critical review of the emerging research evidence on agricultural biodiversity, diet diversity, and nutritional status in low- and middle-income countries. Nutr. Rev. 75, 769-782. https://doi.org/10.1093/nutrit/nux040.

Jones, A.D., Cruz Agudo, Y., Galway, L., Bentley, J., Pinstrup-Andersen, P., 2012. Heavy agricultural workloads and low crop diversity are strong barriers to improving child feeding practices in the Bolivian Andes. Soc. Sci. Med. 75, 1673-1684. https://doi.org/10.1016/j.socscimed.2012.06.025.

Jones, A.D., Shrinivas, A., Bezner-Kerr, R., 2014. Farm production diversity is associated with greater household dietary diversity in Malawi: Findings from nationally representative data. Food Policy 46, 1-12. https://doi.org/10.1016/j.foodpol.2014.02.001.

Kadiyala, S., Harris, J., Headey, D., Yosef, S., Gillespie, S., 2014. Agriculture and nutrition in India: mapping evidence to pathways. Ann. N. Y. Acad. Sci. 1331, 43-56. https://doi.org/10.1111/nyas.12477.

Kalavathi, S., Krishnakumar, V.P., Thomas, R.J., Thomas, G.V., George, M.L., 2010. Improving food and nutritional security of small and marginal coconut growers 
through diversification of crops and enterprises. J. Agric. Rural Dev. Tropics Subtropics 111, 101-109.

Kaufer, L., Englberger, L., Cue, R., Lorens, A., Albert, K., Pedrus, P., Kuhnlein, H.V., 2010. Evaluation of a "traditional food for health" intervention in Pohnpei, Federated States of Micronesia. Pac. Health Dialog 16, 61-73.

Keding, G.B., Msuya, J.M., Maass, B.L., Krawinkel, M.B., 2012. Relating dietary diversity and food variety scores to vegetable production and socio-economic status of women in rural Tanzania. Food Secur. 4, 129-140. https://doi.org/10.1007/s12571-011-0163y.

Kennedy, G.L., Pedro, M.R., Seghieri, C., Nantel, G., Brouwer, I., 2007. Dietary Diversity Score Is a Useful Indicator of Micronutrient Intake in Non-Breast-Feeding Filipino Children. J. Nutr. 137, 472-477.

Koppmair, S., Kassie, M., Qaim, M., 2017. Farm production, market access and dietary diversity in Malawi. Publ. Health Nutr. 20, 325-335. https://doi.org/10.1017/S1368980016002135.

Kumar, N., Harris, J., Rawat, R., 2015. If They Grow It, Will They Eat and Grow? Evidence from Zambia on Agricultural Diversity and Child Undernutrition. J. Dev. Stud. 51, 1060-1077. https://doi.org/10.1080/00220388.2015.1018901.

Leonardo, W.J., Florin, M.J., van de Ven, G.W.J., Udo, H., Giller, K.E., 2015. Which smallholder farmers benefit most from biomass production for food and biofuel? The case of Gondola district, central Mozambique. Biomass Bioenergy 83, 257-268. https://doi.org/10.1016/j.biombioe.2015.09.016.

Malapit, H.J.L., Quisumbing, A.R., 2015. What dimensions of women's empowerment in agriculture matter for nutrition in Ghana? Food Policy 52, 54-63. https://doi.org/10.1016/j.foodpol.2015.02.003.

Malapit, H.J.L., Kadiyala, S., Quisumbing, A.R., Cunningham, K., Tyagi, P., 2015. Women's Empowerment Mitigates the Negative Effects of Low Production Diversity on Maternal and Child Nutrition in Nepal. J. Dev. Stud. 51, 1097-1123. https://doi.org/10.1080/00220388.2015.1018904.

Mango, N., Zamasiya, B., Makate, C., Nyikahadzoi, K., Siziba, S., 2014. Factors influencing household food security among smallholder farmers in the Mudzi district of Zimbabwe. Dev. South Afr. 31, 625-640. https://doi.org/10.1080/0376835X.2014.911694.

Martin-Prével, Y., Allemand, P., Wiesmann, D., Arimond, M., Ballard, T., Deitchler, M.,Dop, M.-C., Kennedy, G., Lee, W.T., Moursi, M., 2015. Moving forward on choosing a standard operational indicator of women's dietary diversity. FAO.

Masset, E., Haddad, L., Cornelius, A., Isaza-Castro, J., 2012. Effectiveness of agricultural interventions that aim to improve nutritional status of children: systematic review. BMJ 344 d8222.

Mayanja, M., Rubaire-Akiiki, C., Morton, J., Young, S., Greiner, T., 2015. Diet Diversity in Pastoral and Agro-pastoral Households in Ugandan Rangeland Ecosystems. Ecol. Food Nutr. 54, 529-545. https://doi.org/10.1080/03670244.2015.1041135.

McDonald, C.M., McLean, J., Kroeun, H., Talukder, A., Lynd, L.D., Green, T.J., 2015. Correlates of household food insecurity and low dietary diversity in rural Cambodia. Asia Pac. J. Clin. Nutr. 24, 720-730. 
Mirmiran, P., Azadbakht, L., Esmaillzadeh, A., Azizi, F., 2004. Dietary diversity score in adolescents - a good indicator of the nutritional adequacy of diets: Tehran lipid and glucose study. Asia Pac. J. Clin. Nutr. 13, 56-60.

Moltedo, A., Sánchez, C.Á., Troubat, N., Cafiero, C., 2018. Optimizing the use of ADePTFood Security Module for Nutrient Analysis.

Moursi, M.M., Arimond, M., Dewey, K.G., Trèche, S., Ruel, M.T., Delpeuch, F., 2008. Dietary diversity is a good predictor of the micronutrient density of the diet of 6- to 23-month-old children in Madagascar. J. Nutr. 138, 2448-2453. https://doi.org/10.3945/jn.108.093971.

Murphy, S., Ruel, M., Carriquiry, A., 2012. Should Household Consumption and Expenditures Surveys (HCES) be Used for Nutritional Assessment and Planning? Food Nutr. Bull. 33, S235-S241. https://doi.org/10.1177/15648265120333S213.

M'Kaibi, F.K., Steyn, N.P., Ochola, S.A., Du Plessis, L., 2017. The relationship between agricultural biodiversity, dietary diversity, household food security, and stunting of children in rural Kenya. Food Sci. Nutr. 5, 243-254. https://doi.org/10.1002/fsn3.387.

Nguyen, P.H., Huybregts, L., Sanghvi, T.G., Tran, L.M., Frongillo, E.A., Menon, P., Ruel, M.T., 2018. J. Dietary Diversity Predicts the Adequacy of Micronutrient Intake in Pregnant Adolescent Girls and Women in Bangladesh, but Use of the 5-Group Cutoff Poorly Identifies Individuals with Inadequate Intake. Nutrition 148, 790-797. https://doi.org/10.1093/jn/nxy045.

Ng'endo, M., Bhagwat, S., Keding, G.B., 2016. Influence of Seasonal On-Farm Diversity on Dietary Diversity: A Case Study of Smallholder Farming Households in Western Kenya. Ecol. Food Nutr. 55, 403-427. https://doi.org/10.1080/03670244.2016.1200037.

NIH-NCI, 2018. Dietary Assessment Primer. Choosing an approach. Recommendations. National Institutes of Health, National Cancer Institute. https://dietassessmentprimer.cancer.gov/, Accessed date: 19 October 2018.

Olney, D.K., Talukder, A., Iannotti, L.L., Ruel, M.T., Quinn, V., 2009. Assessing impact and impact pathways of a homestead food production program on household and child nutrition in Cambodia. Food Nutr. Bull. 30, 355-369.

Olney, D.K., Bliznashka, L., Pedehombga, A., Dillon, A., Ruel, M.T., Heckert, J., 2016. A 2Year Integrated Agriculture and Nutrition Program Targeted to Mothers of Young Children in Burkina Faso Reduces Underweight among Mothers and Increases Their Empowerment: A Cluster-Randomized Controlled Trial. J. Nutr. 146, 1109-1117. https://doi.org/10.3945/jn.115.224261.

Pandey, V.L., Mahendra Dev, S., Jayachandran, U., 2016. Impact of agricultural interventions on the nutritional status in South Asia: A review. Food Policy 62, 28-40. https://doi.org/10.1016/j.foodpol.2016.05.002.

Pellegrini, L., Tasciotti, L., 2014. Crop diversification, dietary diversity and agricultural income: empirical evidence from eight developing countries. Can. J. Dev. Stud. Rev. Can. Détudes Dév. 35, 211-227. https://doi.org/10.1080/02255189.2014.898580.

Penafiel, D., Lachat, C., Espinel, R., Van Damme, P., Kolsteren, P., 2011. A systematic review on the contributions of edible plant and animal biodiversity to human diets. EcoHealth 8, 381-399. https://doi.org/10.1007/s10393-011-0700-3. 
Powell, B., Thilsted, S.H., Ickowitz, A., Termote, C., Sunderland, T., Herforth, A., 2015. Improving diets with wild and cultivated biodiversity from across the landscape. Food Secur. 7, 535-554. https://doi.org/10.1007/s12571-015-0466-5.

Rathnayake, K.M., Madushani, P., Silva, K., 2012. Use of dietary diversity score as a proxy indicator of nutrient adequacy of rural elderly people in Sri Lanka. BMC Res. Notes 5, 469. https://doi.org/10.1186/1756-0500-5-469.

Rawlins, R., Pimkina, S., Barrett, C.B., Pedersen, S., Wydick, B., 2014. Got milk? The impact of Heifer International's livestock donation programs in Rwanda on nutritional outcomes. Food Policy 44, 202-213. https://doi.org/10.1016/j.foodpol.2013.12.003.

Remans, R., Flynn, D.F.B., DeClerck, F., Diru, W., Fanzo, J., Gaynor, K., Lambrecht, I., Mudiope, J., Mutuo, P.K., Nkhoma, P., Siriri, D., Sullivan, C., Palm, C.A., 2011. Assessing nutritional diversity of cropping systems in African villages. PLoS One 6 e21235. https://doi.org/10.1371/journal.pone.0021235.

Romeo, A., Meerman, J., Demeke, M., Scognamillo, A., Asfaw, S., 2016. Linking farm diversification to household diet diversification: evidence from a sample of Kenyan ultra-poor farmers. Food Secur. 8, 1069-1085. https://doi.org/10.1007/s12571-0160617-3.

Ruel, M.T., 2003. Operationalizing dietary diversity: a review of measurement issues and research priorities. J. Nutr. 133, 3911S-3926S.

Ruel, M.T., Alderman, H., 2013. Nutrition-sensitive interventions and programmes: how can they help to accelerate progress in improving maternal and child nutrition? Lancet 382, 536-551. https://doi.org/10.1016/S0140-6736(13)60843-0.

Selvester, K., Fidalgo, L., Ballard, T., Kennedy, G., Dop, M.C., Mistura, L., Deitchler, M., 2008. Report on use of the Household Food Insecurity Access Scale and Household Dietary Diversity Score in two survey rounds in Manica and Sofala Provinces, Mozambique, 2006-2007. FAO food security project GCP. MOZ/079/BEL. Version 2. FAO.

Sibhatu, K.T., Qaim, M., 2018. Review: Meta-analysis of the association between production diversity, diets, and nutrition in smallholder farm households. Food Policy 77, 1-18. https://doi.org/10.1016/j.foodpol.2018.04.013.

Sibhatu, K.T., Krishna, V.V., Qaim, M., 2015. Production diversity and dietary diversity in smallholder farm households. Proc. Natl. Acad. Sci. U. S. A 112, 10657-10662. https://doi.org/10.1073/pnas.1510982112.

Smale, M., Moursi, M., Birol, E., 2015. How does adopting hybrid maize affect dietary diversity on family farms? Micro-evidence from Zambia. Food Policy 52, 44-53. https://doi.org/10.1016/j.foodpol.2015.03.001.

Smith, L.C., Dupriez, O., Troubat, N., 2014. Assessment of the reliability and relevance of the food data collected in national household consumption and expenditure surveys. Int. Househ. Surv. Netw.

Snapp, S.S., Fisher, M., 2015. "Filling the maize basket" supports crop diversity and quality of household diet in Malawi. Food Secur. 7, 83-96. https://doi.org/10.1007/s12571014-0410-0.

Sraboni, E., Malapit, H.J., Quisumbing, A.R., Ahmed, A.U., 2014. Women's Empowerment in Agriculture: What Role for Food Security in Bangladesh? World Dev. 61, 11-52. https://doi.org/10.1016/j.worlddev.2014.03.025. 
Steyn, N.P., Nel, J., Labadarios, D., Maunder, E.M.W., Kruger, H.S., 2014. Which dietary diversity indicator is best to assess micronutrient adequacy in children 1 to $9 \mathrm{y}$ ? Nutrition 30, 55-60. https://doi.org/10.1016/j.nut.2013.06.002.

Swindale, A., Bilinsky, P., 2006. Household Dietary Diversity Score (HDDS) for Measurement of Household Food Access: Indicator Guide (v.2).

Tavakoli, S., Dorosty-Motlagh, A.R., Hoshiar-Rad, A., Eshraghian, M.R., Sotoudeh, G., Azadbakht, L., Karimi, M., Jalali-Farahani, S., 2016. Is dietary diversity a proxy measurement of nutrient adequacy in Iranian elderly women? Appetite 105, 468-476. https://doi.org/10.1016/j.appet.2016.06.011.

Tessema, M., Belachew, T., Ersino, G., 2013. Feeding patterns and stunting during early childhood in rural communities of Sidama, South Ethiopia. Pan Afr. Med. J. 14, 75. https://doi.org/10.11604/pamj.2013.14.75.1630.

UNICEF, 1990. Strategy for Improved Nutrition of Children and Women in Developing Countries. UNICEF.

Walton, C., Taylor, J., VanLeeuwen, J., Yeudall, F., Mbugua, S., 2014. Associations of diet quality with dairy group membership, membership duration and non- membership for Kenyan farm women and children: a comparative study. Publ. Health Nutr. 17, 307316. https://doi.org/10.1017/S1368980012005010.

Warren, E., Hawkesworth, S., Knai, C., 2015. Investigating the association between urban agriculture and food security, dietary diversity, and nutritional status: A systematic literature review. Food Policy 53, 54-66. https://doi.org/10.1016/j.foodpol.2015.03.004.

Webb, P., Kennedy, E., 2014. Impacts of agriculture on nutrition: nature of the evidence and research gaps. Food Nutr. Bull. 35, 126-132.

World Health Organization, 1996. Preparation and use of food-based dietary guides: report of a joint FAO/WHO Expert Consultation, Nicosia, Cyprus. In: Preparation and Use of Food-Based Dietary Guidelines: Report of a Joint FAO/WHO Consultation. Geneva.

World Health Organization, 2008. Indicators for assessing infant and young child feeding practices. Part 1: Definitions.

World Health Organization, 2010. Indicators for assessing infant and young child feeding practices. Part II: Measurement.

Wiesmann, D., Arimond, M., Loechl, C., 2009. Dietary Diversity as a Measure of the Micronutrient Adequacy of Women's Diets: Results from Rural Mozambique Site. Food and Nutrition Technical Assistance II Project. FHI 360, Washington, DC.

Women's Dietary Diversity Project (WDDP) Study Group, 2017. Development of a Dichotomous Indicator for Population-Level Assessment of Dietary Diversity in Women of Reproductive Age. Current Developments in Nutrition 1 (12) cdn.117.001701. https://doi.org/10.3945/cdn.117.001701.

Working Group on Infant and Young Child Feeding Indicators, 2006. Developing and Validating Simple Indicators of Dietary Quality of Infants and Young Children in Developing Countries: Summary of findings from analysis of 10 data sets. Food and Nutrition Technical Assistance II Project. FHI 360, Washington, DC.

World Bank, 2007. From agriculture to nutrition. Pathways, synergies and outcomes. 
Zezza, A., Tasciotti, L., 2010. Urban agriculture, poverty, and food security: Empirical evidence from a sample of developing countries. Food Policy 35, 265-273.

660 https://doi.org/10.1016/j.foodpol.2010.04.007. 


\section{Figures, Tables and Boxes}

Peer-reviewed articles, written in English, published after 2006 and released up to and including 23 May 2017, identified through database searching on PubMed $(n=70)$, Web of Science $(n=73)$ and Science direct $(n=42)$

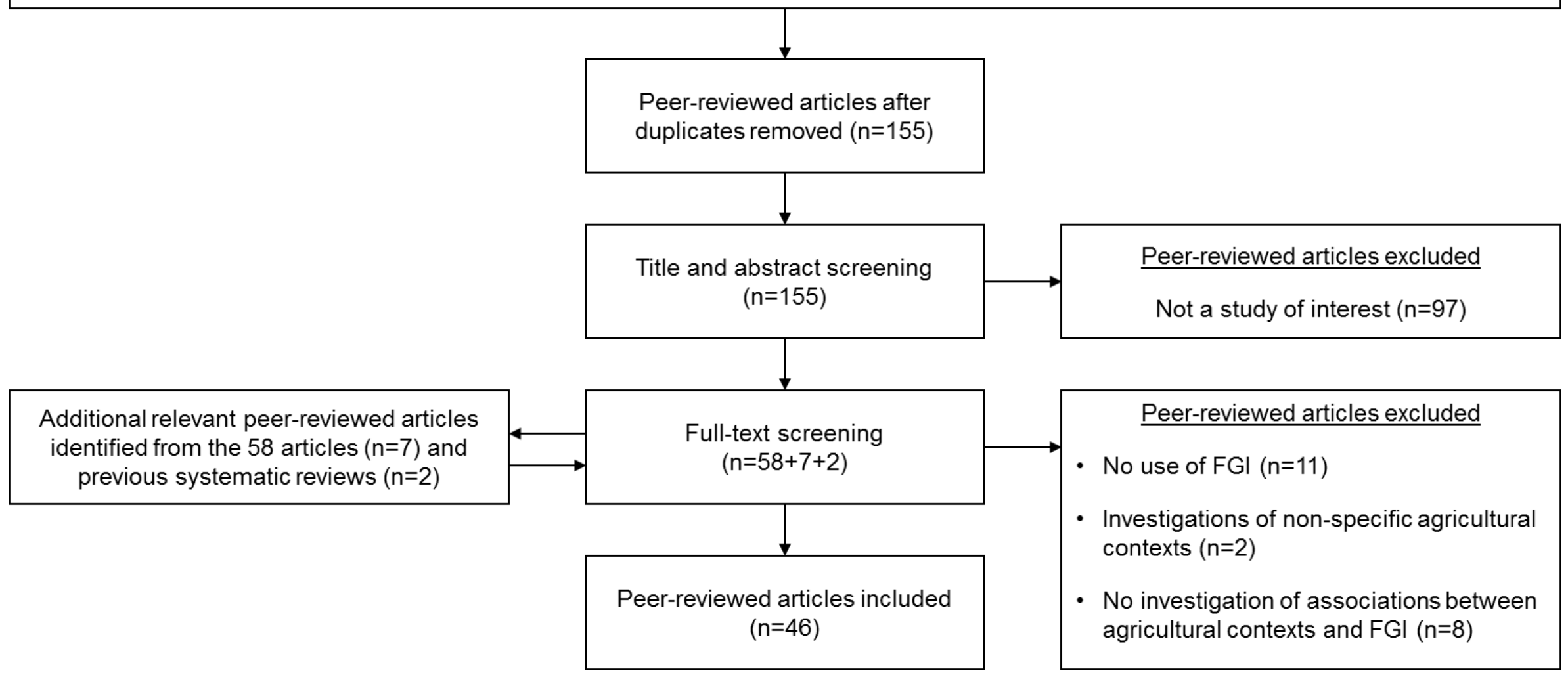

Fig. 1 Systematic literature review article selection flowchart 
Table 1. Characteristics of four standard food group indicators of dietary diversity.

\begin{tabular}{|c|c|c|c|c|}
\hline Characteristics & $\begin{array}{l}\text { Household Dietary Diversity Score } \\
\text { (HDDS) }\end{array}$ & Minimum Dietary Diversity (MDD) & $\begin{array}{l}\text { Women's Dietary Diversity Score } \\
\text { (WDDS) }\end{array}$ & $\begin{array}{l}\text { Minimum Dietary Diversity for Women } \\
\text { of Reproductive Age (MDD-W) }\end{array}$ \\
\hline $\begin{array}{l}\text { Unit of } \\
\text { analysis }\end{array}$ & Household & Individual & Individual & Individual \\
\hline Purpose & $\begin{array}{l}\text { To reflect the economic ability of a } \\
\text { household to access a variety of foods } \\
\text { (access dimension of household food } \\
\text { security) }\end{array}$ & $\begin{array}{l}\text { Proxy of adequate micronutrient density } \\
\text { of complementary foods of infant and } \\
\text { young children aged } 6 \text { to } 23 \text { months }\end{array}$ & $\begin{array}{l}\text { Proxy of micronutrient adequacy of diets } \\
\text { of women of reproductive age }\end{array}$ & $\begin{array}{l}\text { Proxy of micronutrient adequacy of diets } \\
\text { of women of reproductive age }\end{array}$ \\
\hline Validitation & $\begin{array}{l}\text { Positively associated with household per } \\
\text { capita energy availability in datasets } \\
\text { from } 10 \text { countries (Hoddinott and } \\
\text { Yohannes, 2002) }\end{array}$ & $\begin{array}{l}\text { Positively associated with the mean } \\
\text { micronutrient density adequacy of } \\
\text { complementary foods of breastfed and } \\
\text { nonbreastfed infants and young children } \\
\text { aged } 6 \text { to } 23 \text { months in } 10 \text { datasets } \\
\text { (Working Group on Infant and Young, } \\
\text { 2006) }\end{array}$ & $\begin{array}{l}\text { Positively associated with the mean } \\
\text { probability of adequacy across } 11 \\
\text { micronutrients in } 5 \text { datasets (Arimond et } \\
\text { al., 2010)* }\end{array}$ & $\begin{array}{l}\text { Positively associated with the mean } \\
\text { probability of adequacy across } 11 \\
\text { micronutrients in } 9 \text { datasets (Women's } \\
\text { Dietary Diversity Project Study Group, } \\
\text { 2017) }\end{array}$ \\
\hline $\begin{array}{l}\text { Dietary } \\
\text { assessment } \\
\text { and reference } \\
\text { period }\end{array}$ & $\begin{array}{l}\text { 24-hour recall, inclusion all of foods } \\
\text { consumed by household members in the } \\
\text { home (consumption outside of the home } \\
\text { not included) }\end{array}$ & $\begin{array}{l}\text { 24-hour recall, inclusion of all foods } \\
\text { eaten by the infant or child }\end{array}$ & $\begin{array}{l}\text { 24-hour recall, inclusion of all foods } \\
\text { eaten by the individual (the correlation } \\
\text { between WDDS and mean probability of } \\
\text { adequacy was improved when foods } \\
\text { consumed in quantities }<15 \mathrm{~g} \text { were not } \\
\text { included) }\end{array}$ & $\begin{array}{l}\text { 24-hour recall, inclusion of all foods } \\
\text { eaten by the individual (the correlation } \\
\text { between food group diversity and mean } \\
\text { probability of adequacy was improved } \\
\text { when foods consumed in quantities }<15 \mathrm{~g} \\
\text { were not included) }\end{array}$ \\
\hline $\begin{array}{l}\text { Food } \\
\text { classification }\end{array}$ & $\begin{array}{l}12 \text { food groups: Cereals; White roots and } \\
\text { tubers; Vegetables; Fruits; Meat; Eggs; } \\
\text { Fish and seafood; Legumes, nuts, and } \\
\text { seeds; Milk and milk products; Oils and } \\
\text { fats; Sweets; Spices, condiments, and } \\
\text { beverages }\end{array}$ & $\begin{array}{l}7 \text { food groups: Grains, roots, and tubers; } \\
\text { Legumes and nuts; Dairy products; } \\
\text { Flesh foods; Eggs; Vitamin A-rich fruits } \\
\text { and vegetables; Other fruits and } \\
\text { vegetables }\end{array}$ & $\begin{array}{l}9 \text { food groups: Starchy staples; Dark } \\
\text { green leafy vegetables; Other vitamin } \\
\text { A-rich fruits and vegetables; Other } \\
\text { fruits and vegetables; Organ meat; Meat } \\
\text { and fish; Eggs; Legumes, nuts, and } \\
\text { seeds; Milk and milk products }\end{array}$ & $\begin{array}{l}10 \text { food groups: Grains, white roots and } \\
\text { tubers, and plantains; Pulses; Nuts and } \\
\text { seeds; Dairy; Meat, poultry and fish; } \\
\text { Eggs; Dark green leafy vegetables; } \\
\text { Other vitamin A-rich fruits and } \\
\text { vegetables; Other vegetables; Other } \\
\text { fruits }\end{array}$ \\
\hline Score & Count of food groups consumed: $0-12$ & Count of food groups consumed: $0-7$ & Count of food groups consumed: 0-9 & Count of food groups consumed: $0-10$ \\
\hline $\begin{array}{l}\text { Dichotomous } \\
\text { indicator\$ }\end{array}$ & $\begin{array}{l}\text { No dichotomous indicator but } \\
\text { suggestion to use distribution of scores } \\
\text { (quantiles) for analytical purposes }\end{array}$ & $\begin{array}{l}\text { Minimum Dietary Diversity }=4 \text { or more } \\
\text { of the } 7 \text { food groups }\end{array}$ & $\begin{array}{l}\text { No dichotomous indicator but } \\
\text { suggestion to use distribution of scores } \\
\text { (quantiles) for analytical purposes }\end{array}$ & $\begin{array}{l}\text { Minimum Dietary Diversity for women } \\
=5 \text { or more of the } 10 \text { food groups }\end{array}$ \\
\hline Guidelines & $\begin{array}{l}\text { Swindale and Bilinsky (2006) and FAO } \\
\text { (2011) }\end{array}$ & WHO (2008) and WHO (2010) & FAO (2011) & FAO and FHI 360 (2016) \\
\hline
\end{tabular}


*The validation study tested four different food group combinations (dietary diversity scores based on 6, 9, 13 or 21 food groups). The conclusion was that all dietary diversity scores were significantly correlated with micronutrient adequacy of the diet, the 21-food group indicator showing the highest correlation (Arimond et al., 2010). The FAO guidelines proposed to use the 9-food group indicator because it was easier to operationalize (FAO, 2011).

${ }^{\$}$ For MDD and MDD-W, a cut-point was validated against micronutrient adequacy of diets and the indicator is expressed as the percent of individuals consuming a number of food groups equal to or above the cut-point. 
Table 2. Assessment of the use and interpretation of food group indicators of dietary diversity

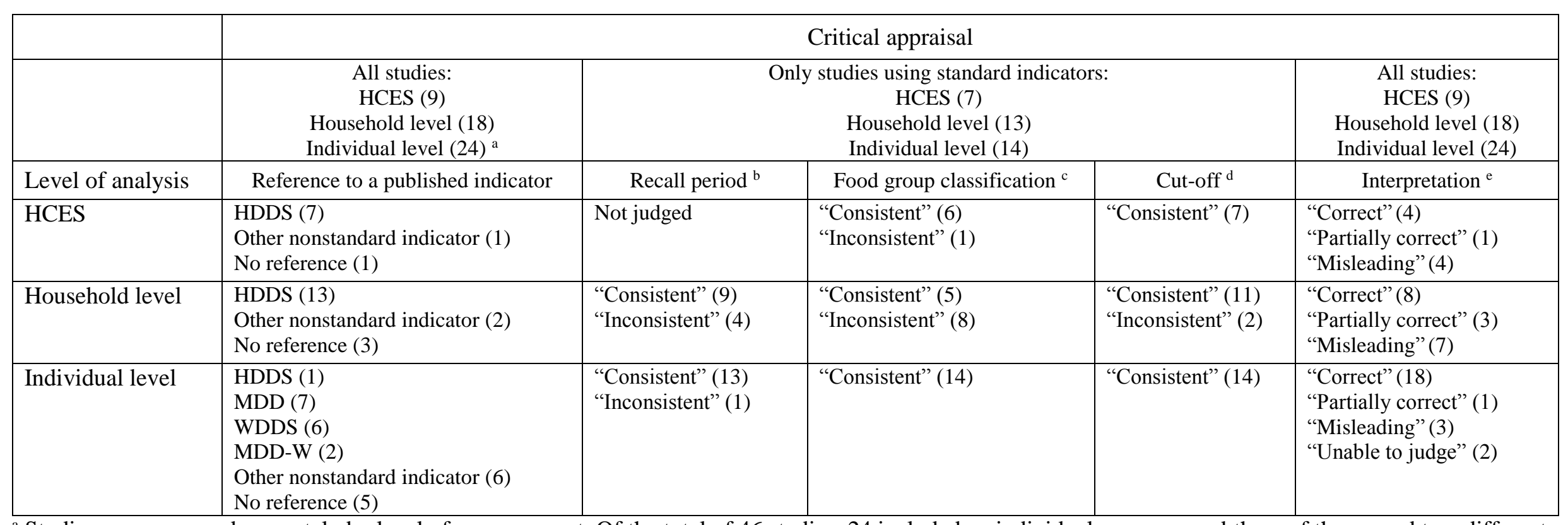

${ }^{a}$ Studies were assessed separately by level of measurement. Of the total of 46 studies, 24 included an individual measure, and three of those used two different indicators (children and women). Therefore a total of 27 individual level indicators were assessed under the first criterion of standard FGIs. Because five studies measured dietary diversity at both the household and individual level, the assessment was applied to 9 HCES, 18 individual level studies (13+5) and 24 individual level studies $(19+5)$.

b "Consistent" if used a $24-\mathrm{h}$ recall.

c "Consistent" if used 12 food groups with standard categories for HDDS, 7 food groups with standard categories for MDD; 9 food groups with standard categories for WDDS; and 10 food groups with standard categories for MDD-W.

d "Consistent" if used the recommended cut-off for standard indicators (MDD, MDD-W) or, in the case of indicators without a recommended cut-off (HDDS, WDDS), either did not use a cut-off or applied quantiles based on the score distribution.

e "Correct" if interpretation of the indicator was consistent with the objective of the study and the level of analysis; "partially correct" if the interpretation was consistent with the level of analysis but either the indicator was inappropriate or, somewhere in the paper, a household level indicator was mislabelled as measuring nutrition or diet quality; "misleading" if the interpretation of the indicator was not consistent with the objective of the study and level of analysis; and "unable to judge" when essential information was missing on the level of analysis or purpose of measuring dietary diversity. 
Box 1. Checklist of items that should be described when reporting on use of dietary diversity indicators

\begin{tabular}{|c|c|c|}
\hline Checklist item & \# & Description of the item \\
\hline Objective & 1 & $\begin{array}{l}\text { Describe the objective of the measurement of dietary diversity (household food security or } \\
\text { individual nutrient adequacy of the diet) }\end{array}$ \\
\hline Unit of analysis & 2 & $\begin{array}{l}\text { a) Identify whether dietary diversity is measured at the household and/or individual level } \\
\text { b) If the measure is at the individual level, specify the sex and age group of the subjects, and the } \\
\text { physiological status for women }\end{array}$ \\
\hline Reference & 3 & Refer to a guidance manual if a standard FGI is used \\
\hline Respondent & 4 & Describe who responded to the questions and whose diet was referred to \\
\hline Recall period & 5 & $\begin{array}{l}\text { a) Report the recall period } \\
\text { b) If a recall period greater than } 24 \mathrm{~h} \text { is applied to an otherwise standard FGI, provide an } \\
\text { explanation. }\end{array}$ \\
\hline $\begin{array}{l}\text { Food group } \\
\text { classification }\end{array}$ & 6 & $\begin{array}{l}\text { Provide detailed information on the food group classification used to construct the FGI (e.g. total } \\
\text { number and names the food groups) }\end{array}$ \\
\hline Score & 7 & Report how the FGI was computed \\
\hline Cut-off point & 8 & $\begin{array}{l}\text { Specify whether a cut-off point was used to create a dichotomous indicator or whether the } \\
\text { distribution of the score (e.g. quantiles) was used for analytical purposes }\end{array}$ \\
\hline
\end{tabular}


Appendix A. Characteristics of household consumption and expenditure surveys using food group indicators of dietary diversity and assessment of their use and interpretation $(n=9)$

\begin{tabular}{|c|c|c|c|c|c|c|c|c|c|}
\hline \multirow[b]{2}{*}{ Study } & \multirow[b]{2}{*}{ Location } & \multirow[b]{2}{*}{$\begin{array}{l}\text { Study } \\
\text { design }\end{array}$} & \multirow[b]{2}{*}{ Subjects and sample size } & \multicolumn{6}{|c|}{ Critical appraisal and details of the FGI } \\
\hline & & & & $\begin{array}{l}\text { Is the FGI a } \\
\text { standard one? }\end{array}$ & Reference & Recall period & $\begin{array}{l}\text { Food group } \\
\text { classification }\end{array}$ & Cut-off & $\begin{array}{l}\text { Interpretation of } \\
\text { the FGI }\end{array}$ \\
\hline $\begin{array}{l}\text { Jones et al. } \\
\text { (2014) }\end{array}$ & Malawi & $\begin{array}{l}\text { Secondary } \\
\text { analysis of } \\
\text { cross- } \\
\text { sectional } \\
\text { survey }\end{array}$ & $\begin{array}{l}\text { Smallholder farmers } \\
(\mathrm{n}=6623)\end{array}$ & Yes & $\begin{array}{l}\text { HDDS } \\
\text { (Swindale and } \\
\text { Bilinsky, 2006) }\end{array}$ & $\begin{array}{l}\text { Not judged } \\
\text { Previous } 7 \text { days }\end{array}$ & $\begin{array}{l}\text { Consistent } \\
12 \text { food group } \\
\text { classification, } \\
\text { based on } \\
\text { consumption of } \\
135 \text { food items }\end{array}$ & $\begin{array}{l}\text { Consistent } \\
\text { No use of cut-off }\end{array}$ & $\begin{array}{l}\text { Correct } \\
\text { But one sentence } \\
\text { presenting the } \\
\text { diversity of } \\
\text { household diets as } \\
\text { an important } \\
\text { nutrition outcome } \\
\text { associated with } \\
\text { the nutrient } \\
\text { adequacy of diets } \\
\text { is misleading. }\end{array}$ \\
\hline $\begin{array}{l}\text { Pellegrini } \\
\text { and } \\
\text { Tasciotti } \\
(2014)\end{array}$ & $\begin{array}{l}\text { - Albania } \\
\text { - Indonesia } \\
\text { - Malawi } \\
\text { - Nepal } \\
\text { - Nicaragua } \\
\text { - Pakistan } \\
\text { - Panama } \\
\text { - Vietnam }\end{array}$ & $\begin{array}{l}\text { Secondary } \\
\text { analysis of } \\
\text { cross- } \\
\text { sectional } \\
\text { surveys }\end{array}$ & $\begin{array}{l}\text { Households (sample size } \\
\text { unknown) }\end{array}$ & Yes & $\begin{array}{l}\text { HDDS } \\
\text { (FAO, 2008) }\end{array}$ & $\begin{array}{l}\text { Not judged } \\
\text { Range of } 7 \text { to } 365 \\
\text { days across } \\
\text { countries }\end{array}$ & $\begin{array}{l}\text { Inconsistent } \\
13 \text { food group } \\
\text { classification, } \\
\text { based on a range } \\
\text { across countries } \\
\text { of } 24-75 \text { food } \\
\text { items }\end{array}$ & $\begin{array}{l}\text { Consistent } \\
\text { No use of cut-off }\end{array}$ & $\begin{array}{l}\text { Misleading } \\
\text { Interpreted results } \\
\text { of household } \\
\text { dietary diversity } \\
\text { as a measure of } \\
\text { diet quality, } \\
\text { household } \\
\text { nutrition or } \\
\text { nutritional status }\end{array}$ \\
\hline $\begin{array}{l}\text { Sraboni et } \\
\text { al. (2014) }\end{array}$ & Bangladesh & $\begin{array}{l}\text { Secondary } \\
\text { analysis of } \\
\text { cross- } \\
\text { sectional } \\
\text { survey }\end{array}$ & $\begin{array}{l}\text { Farm households } \\
(\mathrm{n}=3273)\end{array}$ & Yes & $\begin{array}{l}\text { HDDS } \\
(\text { FAO, 2011) }\end{array}$ & $\begin{array}{l}\text { Not judged } \\
\text { Previous } 7 \text { days }\end{array}$ & $\begin{array}{l}\text { Consistent } \\
12 \text { food group } \\
\text { classification, } \\
\text { based on } 300 \text { food } \\
\text { items }\end{array}$ & $\begin{array}{l}\text { Consistent } \\
\text { No use of cut-off }\end{array}$ & Correct \\
\hline
\end{tabular}




\begin{tabular}{|c|c|c|c|c|c|c|c|c|c|}
\hline $\begin{array}{l}\text { Benson } \\
(2015)\end{array}$ & Malawi & $\begin{array}{l}\text { Secondary } \\
\text { analysis of } \\
\text { cross- } \\
\text { sectional } \\
\text { survey }\end{array}$ & $\begin{array}{l}\text { Smallholder farmers } \\
(\mathrm{n}=9750)\end{array}$ & Yes & $\begin{array}{l}\text { HDDS } \\
\text { (Swindale and } \\
\text { Bilinsky, 2006) }\end{array}$ & $\begin{array}{l}\text { Not judged } \\
\text { Previous } 7 \text { days }\end{array}$ & $\begin{array}{l}\text { Consistent } \\
12 \text { food group } \\
\text { classification, } \\
\text { based on } 135 \text { food } \\
\text { items. }\end{array}$ & $\begin{array}{l}\text { Consistent } \\
\text { No use of cut-off }\end{array}$ & Correct \\
\hline $\begin{array}{l}\text { Dillon et } \\
\text { al. (2015) }\end{array}$ & Nigeria & $\begin{array}{l}\text { Secondary } \\
\text { analysis of } \\
\text { cross- } \\
\text { sectional } \\
\text { survey }\end{array}$ & $\begin{array}{l}\text { Smallholder farmers } \\
(\mathrm{n}=2154)\end{array}$ & Yes & $\begin{array}{l}\text { HDDS } \\
\text { (FAO 2011) }\end{array}$ & $\begin{array}{l}\text { Not judged } \\
\text { Previous } 7 \text { days }\end{array}$ & $\begin{array}{l}\text { Consistent } \\
12 \text { food group } \\
\text { classification, } \\
\text { based on } 100 \text { food } \\
\text { items. }\end{array}$ & $\begin{array}{l}\text { Consistent } \\
\text { No use of cut-off }\end{array}$ & $\begin{array}{l}\text { Misleading } \\
\text { Interpreted results } \\
\text { of household } \\
\text { dietary diversity } \\
\text { as a measure of } \\
\text { diet quality, } \\
\text { household } \\
\text { nutrition or } \\
\text { nutritional status }\end{array}$ \\
\hline $\begin{array}{l}\text { Sibhatu et } \\
\text { al. (2015) }\end{array}$ & $\begin{array}{l}\text { - Ethiopia } \\
\text { - Indonesia } \\
\text { - Kenya } \\
\text { - Malawi }\end{array}$ & $\begin{array}{l}\text { Secondary } \\
\text { analysis of } \\
\text { cross- } \\
\text { sectional } \\
\text { surveys }\end{array}$ & $\begin{array}{l}\text { Ethiopian }(n=2045) \text {, } \\
\text { Indonesian }(n=674) \text {, } \\
\text { Kenyan }(n=397) \text { and } \\
\text { Malawian smallholder } \\
\text { farmers }(n=5114)\end{array}$ & Yes & $\begin{array}{l}\text { HDDS } \\
\text { (Swindale and } \\
\text { Bilinsky, 2006) } \\
\text { (FAO, 2011) }\end{array}$ & $\begin{array}{l}\text { Not judged } \\
\text { Previous } 7 \text { days }\end{array}$ & $\begin{array}{l}\text { Consistent } \\
12 \text { food group } \\
\text { classification, } \\
\text { based on a range } \\
\text { across countries } \\
\text { of } 25 \text { - } 135 \text { food } \\
\text { items. }\end{array}$ & $\begin{array}{l}\text { Consistent } \\
\text { No use of cut-off }\end{array}$ & $\begin{array}{l}\text { Misleading } \\
\text { Interpreted results } \\
\text { of household } \\
\text { dietary diversity } \\
\text { as a measure of } \\
\text { diet quality, } \\
\text { household } \\
\text { nutrition or } \\
\text { nutritional status }\end{array}$ \\
\hline $\begin{array}{l}\text { Snapp and } \\
\text { Fisher } \\
(2015)\end{array}$ & Malawi & $\begin{array}{l}\text { Secondary } \\
\text { analysis of } \\
\text { cross- } \\
\text { sectional } \\
\text { survey }\end{array}$ & $\begin{array}{l}\text { Smallholder farmers } \\
(\mathrm{n}=9189)\end{array}$ & Yes & $\begin{array}{l}\text { HDDS } \\
\text { (Swindale and } \\
\text { Bilinsky, 2006) }\end{array}$ & $\begin{array}{l}\text { Not judged } \\
\text { Previous } 7 \text { days }\end{array}$ & $\begin{array}{l}\text { Consistent } \\
12 \text { food group } \\
\text { classification, } \\
\text { based on } 135 \text { food } \\
\text { items }\end{array}$ & $\begin{array}{l}\text { Consistent } \\
\text { No use of cut-off }\end{array}$ & $\begin{array}{l}\text { Misleading } \\
\text { Interpreted results } \\
\text { of household } \\
\text { dietary diversity } \\
\text { as a measure of } \\
\text { diet quality, } \\
\text { household } \\
\text { nutrition or } \\
\text { nutritional status }\end{array}$ \\
\hline $\begin{array}{l}\text { Zezza and } \\
\text { Tasciotti, } \\
\text { (2010) }\end{array}$ & $\begin{array}{l}\text { - Ghana } \\
\text { - } \\
\text { Madagascar } \\
\text { - Malawi }\end{array}$ & $\begin{array}{l}\text { Secondary } \\
\text { analysis of } \\
\text { cross- }\end{array}$ & $\begin{array}{l}\text { Urban households (n } \\
\text { from } 1154 \text { to } 5852 \text { ) }\end{array}$ & No & No reference & $\begin{array}{l}\text { Not judged } \\
\text { Previous } 7 \text { days }\end{array}$ & $\begin{array}{l}\text { Not judged } \\
13 \text { food group } \\
\text { classification, } \\
\text { based on a range }\end{array}$ & $\begin{array}{l}\text { Not judged } \\
\text { No use of cut-off }\end{array}$ & $\begin{array}{l}\text { Partially correct } \\
\text { Interpreted results } \\
\text { correctly for level } \\
\text { of analysis but }\end{array}$ \\
\hline
\end{tabular}




\begin{tabular}{|c|c|c|c|c|c|c|c|c|c|}
\hline & $\begin{array}{l}\text { - Nigeria } \\
\text { - Bangladesh } \\
\text { - Indonesia } \\
\text { - Nepal } \\
\text { - Pakistan } \\
\text { - Vietnam } \\
\text { - Albania } \\
\text { - Bulgaria } \\
\text { - Ecuador } \\
\text { - Guatemala } \\
\text { - Nicaragua } \\
\text { - Panama }\end{array}$ & $\begin{array}{l}\text { sectional } \\
\text { survey }\end{array}$ & & & & & $\begin{array}{l}\text { across countries } \\
\text { of } 20-122 \text { food } \\
\text { items. }\end{array}$ & & $\begin{array}{l}\text { stated that the } \\
\text { household FGI } \\
\text { measures } \\
\text { nutrition, diet } \\
\text { quality. }\end{array}$ \\
\hline $\begin{array}{l}\text { Jones } \\
(2017 \mathrm{a})\end{array}$ & Malawi & $\begin{array}{l}\text { Secondary } \\
\text { analysis of } \\
\text { cross- } \\
\text { sectional } \\
\text { surveys }\end{array}$ & $\begin{array}{l}\text { Smallholder farming } \\
\text { households }(\mathrm{n}=3000)\end{array}$ & No & $\begin{array}{l}\text { (FAO and FHI } \\
360,2016)\end{array}$ & $\begin{array}{l}\text { Not judged } \\
\text { Previous } 7 \text { days }\end{array}$ & $\begin{array}{l}\text { Not judged } \\
10 \text { food group } \\
\text { classification of } \\
\text { the MDD-W, } \\
\text { based on } 124 \text { food } \\
\text { items. }\end{array}$ & $\begin{array}{l}\text { Not judged } \\
\text { No use of cut-off }\end{array}$ & Correct \\
\hline
\end{tabular}


Appendix B. Characteristics of studies using food group indicators of dietary diversity at household level and assessment of their use and interpretation $(\mathrm{n}=18)$

\begin{tabular}{|c|c|c|c|c|c|c|c|c|c|}
\hline \multirow[b]{2}{*}{ Study } & \multirow[b]{2}{*}{ Location } & \multirow[b]{2}{*}{$\begin{array}{l}\text { Study } \\
\text { design }\end{array}$} & \multirow[b]{2}{*}{ Subjects and sample size } & \multicolumn{6}{|c|}{ Critical appraisal and details of the FGI } \\
\hline & & & & $\begin{array}{l}\text { Is the FGI a } \\
\text { standard one? }\end{array}$ & Reference & Recall period & $\begin{array}{l}\text { Food group } \\
\text { classification }\end{array}$ & Cut-off & $\begin{array}{l}\text { Interpretation of the } \\
\text { FGI }\end{array}$ \\
\hline $\begin{array}{l}\text { Remans et } \\
\text { al. (2011) }\end{array}$ & $\begin{array}{l}\text { - Ethiopia } \\
\text { - Kenya } \\
\text { - Malawi }\end{array}$ & $\begin{array}{l}\text { Cross- } \\
\text { sectional } \\
\text { survey }\end{array}$ & $\begin{array}{l}\text { Ethiopian }(\mathrm{n}=60) \text {, } \\
\text { Kenyan }(\mathrm{n}=50) \text {, and } \\
\text { Malawian smallholder } \\
\text { farmers }(\mathrm{n}=60)\end{array}$ & Yes & $\begin{array}{l}\text { HDDS } \\
(\text { FAO, 2008) }\end{array}$ & $\begin{array}{l}\text { Consistent } \\
\text { Previous } 24 \\
\text { hours }\end{array}$ & $\begin{array}{l}\text { Inconsistent } \\
15 \text { food group } \\
\text { classification }\end{array}$ & $\begin{array}{l}\text { Consistent } \\
\text { No use of cut-off }\end{array}$ & Correct \\
\hline $\begin{array}{l}\text { Anderman } \\
\text { et al. } \\
\text { (2014) }\end{array}$ & Ghana & $\begin{array}{l}\text { Cross- } \\
\text { sectional } \\
\text { survey }\end{array}$ & $\begin{array}{l}\text { Cacao and oil palm } \\
\text { farmers }(n=100)\end{array}$ & Yes & $\begin{array}{l}\text { HDDS } \\
\text { (FAO, 2008) }\end{array}$ & $\begin{array}{l}\text { Inconsistent } \\
\text { Previous } 30 \\
\text { days. }\end{array}$ & $\begin{array}{l}\text { Inconsistent } \\
13 \text { food group } \\
\text { classification, } \\
\text { based on } 120 \\
\text { food items. }\end{array}$ & $\begin{array}{l}\text { Consistent } \\
\text { No use of cut-off }\end{array}$ & $\begin{array}{l}\text { Misleading } \\
\text { Interpreted results of } \\
\text { household dietary } \\
\text { diversity as a } \\
\text { measure of diet } \\
\text { quality, household } \\
\text { nutrition or } \\
\text { nutritional status }\end{array}$ \\
\hline $\begin{array}{l}\text { Iannotti } \\
\text { and } \\
\text { Lesorogol } \\
(2014)\end{array}$ & Kenya & $\begin{array}{l}\text { Longitudinal } \\
\text { study }\end{array}$ & $\begin{array}{l}\text { Pastoralist households } \\
(\mathrm{n} \approx 200)\end{array}$ & Yes & $\begin{array}{l}\text { HDDS } \\
\text { (Swindale and } \\
\text { Bilinsky, 2006) }\end{array}$ & $\begin{array}{l}\text { Consistent } \\
\text { Previous } 24 \\
\text { hours }\end{array}$ & $\begin{array}{l}\text { Inconsistent } \\
9 \text { food group } \\
\text { classification }\end{array}$ & $\begin{array}{l}\text { Consistent } \\
\text { No use of cut-off }\end{array}$ & $\begin{array}{l}\text { Misleading } \\
\text { Interpreted results of } \\
\text { household dietary } \\
\text { diversity as a } \\
\text { measure of diet } \\
\text { quality, household } \\
\text { nutrition or } \\
\text { nutritional status }\end{array}$ \\
\hline $\begin{array}{l}\text { Mango et } \\
\text { al. (2014) }\end{array}$ & Zimbabwe & $\begin{array}{l}\text { Secondary } \\
\text { analysis of } \\
\text { baseline } \\
\text { survey }\end{array}$ & $\begin{array}{l}\text { Smallholder farmers } \\
(\mathrm{n}=120)\end{array}$ & Yes & $\begin{array}{l}\text { HDDS } \\
\text { (Selvester et al., } \\
2008 \text { ) }\end{array}$ & $\begin{array}{l}\text { Consistent } \\
\text { Previous } 24 \\
\text { hours }\end{array}$ & $\begin{array}{l}\text { Inconsistent } \\
14 \text { food group } \\
\text { classification }\end{array}$ & $\begin{array}{l}\text { Consistent } \\
\text { No use of cut-off }\end{array}$ & $\begin{array}{l}\text { Partially correct } \\
\text { Interpreted results } \\
\text { correctly for level of } \\
\text { analysis but stated } \\
\text { that the household } \\
\text { FGI measures } \\
\text { nutrition, diet } \\
\text { quality. }\end{array}$ \\
\hline
\end{tabular}




\begin{tabular}{|c|c|c|c|c|c|c|c|c|c|}
\hline $\begin{array}{l}\text { Kumar et } \\
\text { al. (2015) }\end{array}$ & Zambia & $\begin{array}{l}\text { Secondary } \\
\text { analysis of } \\
\text { baseline } \\
\text { survey of an } \\
\text { intervention }\end{array}$ & Household $(\mathrm{n}=2785)$ & Yes & $\begin{array}{l}\text { HDDS } \\
(\text { FAO, 2011) }\end{array}$ & $\begin{array}{l}\text { Consistent } \\
\text { Previous } 24 \\
\text { hours }\end{array}$ & $\begin{array}{l}\text { Inconsistent } \\
7 \text { food group } \\
\text { classification of } \\
\text { the MDD }\end{array}$ & $\begin{array}{l}\text { Consistent } \\
\text { No use of cut-off }\end{array}$ & $\begin{array}{l}\text { Partially correct } \\
\text { Interpreted results } \\
\text { correctly for level of } \\
\text { analysis but used an } \\
\text { inappropriate } \\
\text { indicator (individual } \\
\text { FGI to reflect } \\
\text { household food } \\
\text { security/food access). }\end{array}$ \\
\hline $\begin{array}{l}\text { Mayanja } \\
\text { et al. } \\
\text { (2015) }\end{array}$ & Uganda & $\begin{array}{l}\text { Cross- } \\
\text { sectional } \\
\text { survey }\end{array}$ & $\begin{array}{l}\text { Pastoral }(\mathrm{n}=20) \text { and agro- } \\
\text { pastoral households } \\
(\mathrm{n}=59)\end{array}$ & Yes & $\begin{array}{l}\text { HDDS } \\
(\text { FAO, 2011) }\end{array}$ & $\begin{array}{l}\text { Consistent } \\
\text { Previous } 24 \\
\text { hours }\end{array}$ & $\begin{array}{l}\text { Inconsistent } \\
8 \text { food group } \\
\text { classification }\end{array}$ & $\begin{array}{l}\text { Inconsistent } \\
\text { Cut-off of at least } 4 \text { of } \\
\text { the } 8 \text { food groups. }\end{array}$ & $\begin{array}{l}\text { Misleading } \\
\text { Interpreted results of } \\
\text { household dietary } \\
\text { diversity as a } \\
\text { measure of diet } \\
\text { quality, household } \\
\text { nutrition or } \\
\text { nutritional status }\end{array}$ \\
\hline $\begin{array}{l}\text { McDonald } \\
\text { et al. } \\
\text { (2015) }\end{array}$ & Cambodia & $\begin{array}{l}\text { Cross- } \\
\text { sectional } \\
\text { survey }\end{array}$ & $\begin{array}{l}\text { Rural households } \\
(\mathrm{n}=900)\end{array}$ & Yes & $\begin{array}{l}\text { HDDS } \\
\text { (Swindale and } \\
\text { Bilinsky, 2006) }\end{array}$ & $\begin{array}{l}\text { Consistent } \\
\text { Previous } 24 \\
\text { hours }\end{array}$ & $\begin{array}{l}\text { Consistent } \\
12 \text { food group } \\
\text { classification }\end{array}$ & $\begin{array}{l}\text { Inconsistent } \\
\text { HDDS score of <3 } \\
\text { defines a low dietary } \\
\text { diversity }\end{array}$ & Correct \\
\hline $\begin{array}{l}\text { Jodlowski } \\
\text { et al. } \\
\text { (2016) }\end{array}$ & Zambia & $\begin{array}{l}\text { Evaluation } \\
\text { of a year- } \\
\text { and-half } \\
\text { intervention }\end{array}$ & Households $(n=265)$ & Yes & $\begin{array}{l}\text { HDDS } \\
(\text { FAO, 2011) }\end{array}$ & $\begin{array}{l}\text { Consistent } \\
\text { Previous } 24 \\
\text { hours }\end{array}$ & $\begin{array}{l}\text { Inconsistent } \\
13 \text { food group } \\
\text { classification }\end{array}$ & $\begin{array}{l}\text { Consistent } \\
\text { No use of cut-off }\end{array}$ & Correct \\
\hline $\begin{array}{l}\text { Ng'endo } \\
\text { et al. } \\
\text { (2016) }\end{array}$ & Kenya & $\begin{array}{l}\text { Repeated } \\
\text { cross- } \\
\text { sectional }\end{array}$ & $\begin{array}{l}\text { Smallholder farming } \\
\text { households }(\mathrm{n}=30)\end{array}$ & Yes & $\begin{array}{l}\text { HDDS } \\
(\text { FAO, 2011) }\end{array}$ & $\begin{array}{l}\text { Consistent } \\
\text { Previous } 24 \\
\text { hours }\end{array}$ & $\begin{array}{l}\text { Consistent } \\
12 \text { food group } \\
\text { classification }\end{array}$ & $\begin{array}{l}\text { Consistent } \\
\text { Tertiles }\end{array}$ & Correct \\
\hline
\end{tabular}




\begin{tabular}{|c|c|c|c|c|c|c|c|c|c|}
\hline $\begin{array}{l}\text { Olney et } \\
\text { al. (2016) }\end{array}$ & $\begin{array}{l}\text { Burkina } \\
\text { Faso }\end{array}$ & $\begin{array}{l}\text { Evaluation } \\
\text { of a two- } \\
\text { year } \\
\text { intervention } \\
\text { (RTC) }\end{array}$ & $\begin{array}{l}\text { Household (control } \\
\mathrm{n}=506 \text { and treatment } \\
\mathrm{n}=766 \text { ) }\end{array}$ & Yes & $\begin{array}{l}\text { HDDS } \\
\text { (Swindale and } \\
\text { Bilinsky, 2006) }\end{array}$ & $\begin{array}{l}\text { Inconsistent } \\
\text { Previous } 7 \text { days }\end{array}$ & $\begin{array}{l}\text { Consistent } \\
11 \text { food group } \\
\text { classification, } \\
\text { based on } 57 \text { food } \\
\text { items, the egg } \\
\text { food group not } \\
\text { included because } \\
\text { of an oversight }\end{array}$ & $\begin{array}{l}\text { Consistent } \\
\text { No use of cut-off }\end{array}$ & Correct \\
\hline $\begin{array}{l}\text { Romeo et } \\
\text { al. (2016) }\end{array}$ & Kenya & $\begin{array}{l}\text { Cross- } \\
\text { sectional } \\
\text { survey }\end{array}$ & $\begin{array}{l}\text { Poor rural households } \\
(\mathrm{n}=1353)\end{array}$ & Yes & $\begin{array}{l}\text { HDDS } \\
\text { (Swindale and } \\
\text { Bilinsky, 2006) } \\
\text { (FAO, 2011) }\end{array}$ & $\begin{array}{l}\text { Inconsistent } \\
\text { Previous } 7 \text { days }\end{array}$ & $\begin{array}{l}\text { Consistent } \\
12 \text { food group } \\
\text { classification }\end{array}$ & $\begin{array}{l}\text { Consistent } \\
\text { No use of cut-off }\end{array}$ & Correct \\
\hline $\begin{array}{l}\text { Euler et } \\
\text { al. (2017) }\end{array}$ & Indonesia & $\begin{array}{l}\text { Cross- } \\
\text { sectional } \\
\text { survey }\end{array}$ & Farm households $(\mathrm{n}=664)$ & Yes & $\begin{array}{l}\text { HDDS } \\
(\text { FAO, 2011) }\end{array}$ & $\begin{array}{l}\text { Inconsistent } \\
\text { Previous } 7 \text { days }\end{array}$ & $\begin{array}{l}\text { Inconsistent } \\
\text { No description } \\
\text { of the number of } \\
\text { food groups but } \\
\text { may have used } \\
\text { the } 12 \text { food } \\
\text { group } \\
\text { classification, } \\
\text { based on } 134 \\
\text { food items }\end{array}$ & $\begin{array}{l}\text { Consistent } \\
\text { No use of cut-off }\end{array}$ & $\begin{array}{l}\text { Misleading } \\
\text { Interpreted results of } \\
\text { household dietary } \\
\text { diversity as a } \\
\text { measure of diet } \\
\text { quality, household } \\
\text { nutrition or } \\
\text { nutritional status }\end{array}$ \\
\hline $\begin{array}{l}\text { Koppmair } \\
\text { et al. } \\
(2017)\end{array}$ & Malawi & $\begin{array}{l}\text { Cross- } \\
\text { sectional } \\
\text { survey }\end{array}$ & $\begin{array}{l}\text { Smallholder farm } \\
\text { households }(\mathrm{n}=408)\end{array}$ & Yes & $\begin{array}{l}\text { HDDS } \\
(\text { FAO, 2011) }\end{array}$ & $\begin{array}{l}\text { Consistent } \\
\text { Previous } 24 \\
\text { hours }\end{array}$ & $\begin{array}{l}\text { Consistent } \\
12 \text { food group } \\
\text { classification }\end{array}$ & $\begin{array}{l}\text { Consistent } \\
\text { No use of cut-off }\end{array}$ & $\begin{array}{l}\text { Misleading } \\
\text { Interpreted results of } \\
\text { household dietary } \\
\text { diversity as a } \\
\text { measure of diet } \\
\text { quality, household } \\
\text { nutrition or } \\
\text { nutritional status }\end{array}$ \\
\hline $\begin{array}{l}\text { Olney et } \\
\text { al. (2009) }\end{array}$ & Cambodia & $\begin{array}{l}\text { Repeated } \\
\text { cross- } \\
\text { sectional }\end{array}$ & $\begin{array}{l}\text { Household (control } \\
n=200 \text { and treatment } \\
n=299 \text { ) }\end{array}$ & No & No reference & $\begin{array}{l}\text { Not judged } \\
\text { Previous } 3 \text { days }\end{array}$ & $\begin{array}{l}\text { Not judged } \\
6 \text { food group } \\
\text { classification }\end{array}$ & $\begin{array}{l}\text { Not judged } \\
\text { No use of cut-off }\end{array}$ & Correct \\
\hline
\end{tabular}




\begin{tabular}{|c|c|c|c|c|c|c|c|c|c|}
\hline $\begin{array}{l}\text { Gallaher } \\
\text { et al. } \\
(2013)\end{array}$ & Kenya & $\begin{array}{l}\text { Cross- } \\
\text { sectional } \\
\text { survey }\end{array}$ & $\begin{array}{l}\text { Sack gardening } \\
\text { households }(\mathrm{n}=153) \text { and } \\
\text { non-sack gardening } \\
\text { households }(\mathrm{n}=153)\end{array}$ & No & No reference & $\begin{array}{l}\text { Not judged } \\
\text { Previous } 24 \\
\text { hours }\end{array}$ & $\begin{array}{l}\text { Not judged } \\
15 \text { food group } \\
\text { classification }\end{array}$ & $\begin{array}{l}\text { Not judged } \\
\text { No use of cut-off }\end{array}$ & Correct \\
\hline $\begin{array}{l}\text { Darling } \\
\text { (2014) }\end{array}$ & Kenya & $\begin{array}{l}\text { Cross- } \\
\text { sectional } \\
\text { survey }\end{array}$ & Households $(\mathrm{n}=113)$ & No & $\begin{array}{l}\text { (Arimond and } \\
\text { Ruel, 2004b) }\end{array}$ & $\begin{array}{l}\text { Not judged } \\
\text { Previous } 3 \text { days }\end{array}$ & $\begin{array}{l}\text { Not judged } \\
7 \text { food group } \\
\text { classification }\end{array}$ & $\begin{array}{l}\text { Not judged } \\
\text { No use of cut-off }\end{array}$ & $\begin{array}{l}\text { Partially correct } \\
\text { Interpreted results } \\
\text { correctly for level of } \\
\text { analysis but used an } \\
\text { inappropriate } \\
\text { indicator }\end{array}$ \\
\hline $\begin{array}{l}\text { Rawlins et } \\
\text { al. (2014) }\end{array}$ & Rwanda & $\begin{array}{l}\text { Evaluation } \\
\text { of a one } \\
\text { year } \\
\text { intervention }\end{array}$ & Households $(\mathrm{n}=369)$ & No & No reference & $\begin{array}{l}\text { Not judged } \\
\text { Previous } 2 \text { days }\end{array}$ & $\begin{array}{l}\text { Not judged } \\
16 \text { food group } \\
\text { classification }\end{array}$ & $\begin{array}{l}\text { Not judged } \\
\text { No use of cut-off }\end{array}$ & $\begin{array}{l}\text { Misleading } \\
\text { Extrapolated results } \\
\text { from one population } \\
\text { group to other groups }\end{array}$ \\
\hline $\begin{array}{l}\text { Leonardo } \\
\text { et al. } \\
(2015)\end{array}$ & Mozambique & $\begin{array}{l}\text { Cross- } \\
\text { sectional } \\
\text { survey }\end{array}$ & Households $(\mathrm{n}=80)$ & No & $(\mathrm{FAO}, 2011)$ & $\begin{array}{l}\text { Not judged } \\
\text { Previous } 3 \text { days }\end{array}$ & $\begin{array}{l}\text { Not judged } \\
12 \text { food group } \\
\text { classification } \\
\text { that is not fully } \\
\text { described }\end{array}$ & $\begin{array}{l}\text { Not judged } \\
\text { No use of cut-off }\end{array}$ & $\begin{array}{l}\text { Misleading } \\
\text { Interpreted results of } \\
\text { household dietary } \\
\text { diversity as a } \\
\text { measure of diet } \\
\text { quality, household } \\
\text { nutrition or } \\
\text { nutritional status }\end{array}$ \\
\hline
\end{tabular}


Appendix C. Characteristics of studies using food group indicators of dietary diversity at individual level and assessment of their use and interpretation $(n=24)$

\begin{tabular}{|c|c|c|c|c|c|c|c|c|c|}
\hline \multirow[b]{2}{*}{ Study } & \multirow[b]{2}{*}{ Location } & \multirow[b]{2}{*}{$\begin{array}{l}\text { Study } \\
\text { design }\end{array}$} & \multirow[b]{2}{*}{$\begin{array}{l}\text { Subjects and } \\
\text { sample size }\end{array}$} & \multirow[b]{2}{*}{$\begin{array}{l}\text { Is the FGI a } \\
\text { standard one? }\end{array}$} & \multicolumn{5}{|c|}{ Critical appraisal and details of the FGI } \\
\hline & & & & & Reference & Recall period & $\begin{array}{l}\text { Food group } \\
\text { classification }\end{array}$ & Cut-off & $\begin{array}{l}\text { Interpretation of } \\
\text { the FGI }\end{array}$ \\
\hline $\begin{array}{l}\text { Tessema et al. } \\
\text { (2013) }\end{array}$ & Ethopia & $\begin{array}{l}\text { Cross- } \\
\text { sectional } \\
\text { survey }\end{array}$ & $\begin{array}{l}\text { Children 6-23 } \\
\text { months of age } \\
(n=466)\end{array}$ & Yes & $\begin{array}{l}\text { MDD } \\
\text { (WHO, 2008) }\end{array}$ & $\begin{array}{l}\text { Consistent } \\
\text { Previous } 24 \text { hours }\end{array}$ & $\begin{array}{l}\text { Consistent } \\
7 \text { food group } \\
\text { classification }\end{array}$ & $\begin{array}{l}\text { Consistent } \\
\text { Cut-off of at least } \\
4 \text { of the } 7 \text { food } \\
\text { groups }\end{array}$ & Correct \\
\hline $\begin{array}{l}\text { Walton et al. } \\
\text { (2014) }\end{array}$ & Kenya & $\begin{array}{l}\text { Cross- } \\
\text { sectional } \\
\text { survey }\end{array}$ & Women $(n=102)$ & Yes & $\begin{array}{l}\text { WDDS } \\
\text { (Wiesmann et al., } \\
\text { 2009) }\end{array}$ & $\begin{array}{l}\text { Consistent } \\
\text { Previous } 24 \text { hours }\end{array}$ & $\begin{array}{l}\text { Consistent } \\
9 \text { food group } \\
\text { classification }\end{array}$ & $\begin{array}{l}\text { Consistent } \\
\text { No use of cut-off }\end{array}$ & Correct \\
\hline $\begin{array}{l}\text { Beyene et al. } \\
(2015)\end{array}$ & Ethiopia & $\begin{array}{l}\text { Cross- } \\
\text { sectional } \\
\text { survey }\end{array}$ & $\begin{array}{l}\text { Children } 6-23 \\
\text { months of age } \\
(n=920)\end{array}$ & Yes & $\begin{array}{l}\text { MDD } \\
\text { (WHO, 2008) }\end{array}$ & $\begin{array}{l}\text { Consistent } \\
\text { Previous } 24 \text { hours }\end{array}$ & $\begin{array}{l}\text { Consistent } \\
7 \text { food group } \\
\text { classification }\end{array}$ & $\begin{array}{l}\text { Consistent } \\
\text { Cut-off of at least } \\
4 \text { of the } 7 \text { food } \\
\text { groups }\end{array}$ & Correct \\
\hline $\begin{array}{l}\text { Kumar et al. } \\
\text { (2015) }\end{array}$ & Zambia & $\begin{array}{l}\text { Secondary } \\
\text { analysis of } \\
\text { baseline } \\
\text { survey of } \\
\text { an } \\
\text { intervention }\end{array}$ & $\begin{array}{l}\text { Children 6-23 } \\
\text { months of age } \\
(\mathrm{n}=1298)\end{array}$ & Yes & $\begin{array}{l}\text { MDD } \\
\text { (WHO, 2010) }\end{array}$ & $\begin{array}{l}\text { Consistent } \\
\text { Previous } 24 \text { hours }\end{array}$ & $\begin{array}{l}\text { Consistent } \\
7 \text { food group } \\
\text { classification }\end{array}$ & $\begin{array}{l}\text { Consistent } \\
\text { Cut-off of at least } \\
4 \text { of the } 7 \text { food } \\
\text { groups }\end{array}$ & Correct \\
\hline $\begin{array}{l}\text { Malapit and } \\
\text { Quisumbing, } \\
(2015)\end{array}$ & Ghana & $\begin{array}{l}\text { Secondary } \\
\text { analysis of } \\
\text { baseline } \\
\text { data of an } \\
\text { intervention }\end{array}$ & $\begin{array}{l}\text { Mothers }(n=2027) \\
\text { and children 6-23 } \\
\text { months of age } \\
(n=402)\end{array}$ & Yes & $\begin{array}{l}\text { WDDS } \\
(\text { FAO, 2011) } \\
\text { MDD } \\
\text { (WHO, 2010) }\end{array}$ & $\begin{array}{l}\text { Consistent for } \\
\text { both } \\
\text { Previous } 24 \text { hours }\end{array}$ & 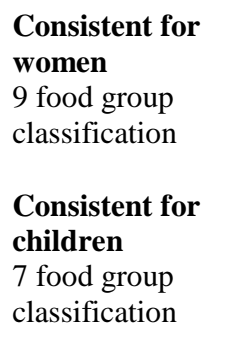 & 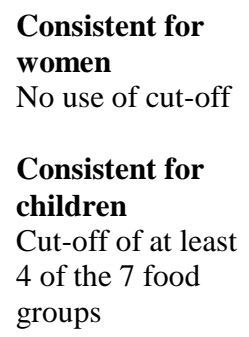 & Correct for both \\
\hline $\begin{array}{l}\text { Malapit et al. } \\
\text { (2015) }\end{array}$ & Nepal & $\begin{array}{l}\text { Secondary } \\
\text { analysis of } \\
\text { cross- }\end{array}$ & Mothers $(n=3076)$ & Yes & $\begin{array}{l}\text { WDDS } \\
\text { (Arimond et al., } \\
2010 \text { ) }\end{array}$ & $\begin{array}{l}\text { Consistent } \\
\text { Previous } 24 \text { hours }\end{array}$ & $\begin{array}{l}\text { Consistent } \\
9 \text { food group } \\
\text { classification that }\end{array}$ & $\begin{array}{l}\text { Consistent } \\
\text { No use of cut-off }\end{array}$ & Correct \\
\hline
\end{tabular}


Bellon et al. Benin

(2016)

Darrouzet- Nepal
Nardi et al.

(2016)

Ng'endo et al. Kenya

(2016)

$\begin{array}{ll}\text { Olney et al. } & \text { Burkina } \\ \text { (2016) } & \text { Faso }\end{array}$

(2016)

Faso

$\begin{array}{ll}\text { Chagomoka } & \text { Burkina } \\ \text { et al. (2017) } & \text { Faso }\end{array}$

Dangura and Ethiopia

Gebremedhin,

(2017)

Dulal et al. Nepal (2017)

\section{Repeated}

cross-

sectional

for the 1

and $n=482$ for the

2nd round)

Evaluation

Children 6 months $\quad$ Yes

of a two- to 8 years of age

year $\quad(\mathrm{n}=589)$

intervention

Repeated Women $(\mathrm{n}=30) \quad$ Yes

cross-

sectional

surveys

\section{Evaluation}

of a two-

year

Mothers of

children 3-12

months of age

intervention (control $\mathrm{n}=506$ and

(RTC) treatment $\mathrm{n}=766$ )

Cross- Women of

sectional reproductive age

survey $\quad(\mathrm{n}=179)$

sectional

Children 6-23

months of age

survey

$(n=417)$

Evaluation Mothers $(\mathrm{n}=2101) \quad$ Yes

of a two- and children 6-23

(lear

$(n=994)$

Yes

Yes

intervention $\quad(\mathrm{n}=994)$
MDD-W

(Daniels and

Ballard, 2014)

MDD

(WHO, 2010)

Consistent

food group

classification

\section{Consistent}

(FAO, 2011)

Previous 24 hou

Consistent

9 food group

classification

(FAO, 2011)
Consistent
Previous 24 hours 9 food group classification

WDDS

(FAO, 2011)

\section{Consistent}

Previous 24 hou

Consisten

9 food group classification that

is not fully

described

\section{MDD \\ (WHO, 2008)}

\section{MDD-W}

(Martin-Prével et

al., 2015)

\section{bot}
Consistent classification

\section{consistent for Consistent for}

Previous 7 days

women

10 food group

classification
Consistent

Cut-off of at least

5 of the 10 food

groups

\section{Consistent}

Cut-off of at least

4 of the 7 food

groups

\section{Consistent}

Tertiles

Correct

\section{Consistent}

No use of cut-off

Correct

Correct 


\begin{tabular}{|c|c|c|c|c|c|c|c|c|c|}
\hline & & & & & $\begin{array}{l}\text { MDD } \\
(\text { FAO, 2011) }\end{array}$ & & $\begin{array}{l}\text { Consistent for } \\
\text { children } \\
7 \text { food group } \\
\text { classification }\end{array}$ & $\begin{array}{l}\text { Consistent for } \\
\text { children } \\
\text { Cut-off of at least } \\
4 \text { of the } 7 \text { food } \\
\text { groups }\end{array}$ & \\
\hline $\begin{array}{l}\text { Koppmair et } \\
\text { al. (2017) }\end{array}$ & Malawi & $\begin{array}{l}\text { Cross- } \\
\text { sectional } \\
\text { survey }\end{array}$ & $\begin{array}{l}\text { Mothers }(n=408) \\
\text { and children under } \\
5 \text { years of age } \\
(n=519)\end{array}$ & Yes & $\begin{array}{l}\text { HDDS } \\
(\text { FAO, 2011) }\end{array}$ & $\begin{array}{l}\text { Consistent for } \\
\text { both } \\
\text { Previous } 24 \text { hours }\end{array}$ & $\begin{array}{l}\text { Consistent for } \\
\text { both } \\
12 \text { food group } \\
\text { classification of } \\
\text { the HDDS }\end{array}$ & $\begin{array}{l}\text { Consistent for } \\
\text { both } \\
\text { No use of cut-off }\end{array}$ & $\begin{array}{l}\text { Partially correct } \\
\text { for both } \\
\text { Interpreted results } \\
\text { correctly for level } \\
\text { of analysis but } \\
\text { used an } \\
\text { inappropriate } \\
\text { indicator }\end{array}$ \\
\hline $\begin{array}{l}\text { Olney et al. } \\
(2009)\end{array}$ & Cambodia & $\begin{array}{l}\text { Repeated } \\
\text { cross- } \\
\text { sectional } \\
\text { surveys }\end{array}$ & $\begin{array}{l}\text { Mothers (control } \\
\mathrm{n}=199 \text { and } \\
\text { treatment } \mathrm{n}=300 \text { ) } \\
\text { and children under } \\
5 \text { years of age } \\
\text { (control } n=199 \text { and } \\
\text { treatment } n=277 \text { ) }\end{array}$ & No & No reference & $\begin{array}{l}\text { Not judged } \\
\text { Previous } 7 \text { days }\end{array}$ & $\begin{array}{l}\text { Not judged } \\
\text { Same } 9 \text { food group } \\
\text { classification for } \\
\text { the children and } \\
\text { women }\end{array}$ & $\begin{array}{l}\text { Not judged } \\
\text { No use of cut-off }\end{array}$ & Correct \\
\hline $\begin{array}{l}\text { Kalavathi et } \\
\text { al. (2010) }\end{array}$ & India & $\begin{array}{l}\text { Evaluation } \\
\text { of a three- } \\
\text { year } \\
\text { intervention } \\
\text { (repeated } \\
\text { cross- } \\
\text { sectional } \\
\text { surveys) }\end{array}$ & $\begin{array}{l}\text { Small and } \\
\text { marginal coconut } \\
\text { homesteads } \\
(\mathrm{n}=150) \text { implying } \\
\text { an unknown } \\
\text { number of adults } \\
\text { and children below } \\
6 \text { years of age }\end{array}$ & No & No reference & $\begin{array}{l}\text { Not judged } \\
\text { Not reported. }\end{array}$ & $\begin{array}{l}\text { Not judged } \\
10 \text { food group } \\
\text { classification }\end{array}$ & $\begin{array}{l}\text { Not judged } \\
\text { Arbitrary } \\
\text { classification in } 5 \\
\text { categories from } \\
\text { "very poor" to } \\
\text { "excellent" (1-3/4- } \\
\text { 5/6-7/8-9/10) }\end{array}$ & $\begin{array}{l}\text { Unable to judge } \\
\text { Insufficient } \\
\text { information for } \\
\text { evaluating the } \\
\text { relevance of the } \\
\text { indicator }\end{array}$ \\
\hline $\begin{array}{l}\text { Kaufer et al. } \\
\text { (2010) }\end{array}$ & $\begin{array}{l}\text { Federated } \\
\text { States of } \\
\text { Micronesia }\end{array}$ & $\begin{array}{l}\text { Evaluation } \\
\text { of a two- } \\
\text { year } \\
\text { intervention }\end{array}$ & Women $(n=40)$ & No & No reference & $\begin{array}{l}\text { Not judged } \\
\text { Previous } 7 \text { days }\end{array}$ & $\begin{array}{l}\text { Not judged } \\
14 \text { food group } \\
\text { classification, } \\
\text { based on } 33 \text { food } \\
\text { items }\end{array}$ & $\begin{array}{l}\text { Not judged } \\
\text { No use of cut-off }\end{array}$ & $\begin{array}{l}\text { Unable to judge } \\
\text { Insufficient } \\
\text { information for } \\
\text { evaluating the } \\
\text { relevance of the } \\
\text { indicator }\end{array}$ \\
\hline $\begin{array}{l}\text { Cabalda et al. } \\
\text { (2011) }\end{array}$ & Philippines & $\begin{array}{l}\text { Cross- } \\
\text { sectional } \\
\text { survey }\end{array}$ & $\begin{array}{l}\text { Children } 2-5 \text { years } \\
\text { of age }(n=200)\end{array}$ & No & $\begin{array}{l}\text { (Kennedy et al., } \\
\text { 2007) }\end{array}$ & $\begin{array}{l}\text { Not judged } \\
\text { Previous } 24 \text { hours }\end{array}$ & $\begin{array}{l}\text { Not judged } \\
10 \text { food group } \\
\text { classification }\end{array}$ & $\begin{array}{l}\text { Not judged } \\
\text { No use of cut-off }\end{array}$ & Correct \\
\hline
\end{tabular}




\begin{tabular}{|c|c|c|c|c|}
\hline $\begin{array}{l}\text { Jones et al. } \\
\text { (2012) }\end{array}$ & Bolivia & $\begin{array}{l}\text { Repeated } \\
\text { cross- } \\
\text { sectional } \\
\text { surveys }\end{array}$ & $\begin{array}{l}\text { Children less than } \\
24 \text { months of age } \\
(n=50)\end{array}$ & No \\
\hline $\begin{array}{l}\text { Keding et al. } \\
\text { (2012) }\end{array}$ & Tanzania & $\begin{array}{l}\text { Repeated } \\
\text { cross- } \\
\text { sectional } \\
\text { surveys }\end{array}$ & $\begin{array}{l}\text { Women involved } \\
\text { in cultivation of } \\
\text { vegetables }(n=252)\end{array}$ & No \\
\hline $\begin{array}{l}\text { De Brauw et } \\
\text { al. }(2015)\end{array}$ & Mozambique & $\begin{array}{l}\text { Evaluation } \\
\text { of a three- } \\
\text { year } \\
\text { intervention } \\
\text { (RCT) }\end{array}$ & $\begin{array}{l}\text { Children 6-35 } \\
\text { months of age } \\
(n=331)\end{array}$ & No \\
\hline $\begin{array}{l}\text { Malapit et al. } \\
\text { (2015) }\end{array}$ & Nepal & $\begin{array}{l}\text { Secondary } \\
\text { analysis of } \\
\text { cross- } \\
\text { sectional } \\
\text { survey }\end{array}$ & $\begin{array}{l}\text { Children 6-59 } \\
\text { months of age } \\
(n=2817)\end{array}$ & No \\
\hline $\begin{array}{l}\text { Smale et al. } \\
(2015)\end{array}$ & Zambia & $\begin{array}{l}\text { Cross- } \\
\text { sectional } \\
\text { survey }\end{array}$ & $\begin{array}{l}\text { Primary female } \\
\text { decision maker in } \\
\text { maize-growing } \\
\text { farm households } \\
(\mathrm{n}=1045)\end{array}$ & No \\
\hline $\begin{array}{l}\text { Hirvonen and } \\
\text { Hoddinott, } \\
\text { (2016) }\end{array}$ & Ethiopia & $\begin{array}{l}\text { Secondary } \\
\text { analysis of } \\
\text { cross- } \\
\text { sectional } \\
\text { survey }\end{array}$ & $\begin{array}{l}\text { Children 6-59 } \\
\text { months of age } \\
(\mathrm{n}=3448)\end{array}$ & No \\
\hline
\end{tabular}

(WHO, 2008)

\section{Not judged}

Not judged

classification

No use of cut-off

$\begin{array}{ll}\text { Not judged } & \text { Not judged } \\ \text { Previous 24 hours } & \begin{array}{l}14 \text { food group } \\ \text { classification }\end{array}\end{array}$

(Reference to several articles to justify how they built the FGI

(Moursi et al.,

$$
\begin{array}{ll}
\text { Not judged } & \text { Not judged } \\
\text { Previous 24 hours } & \begin{array}{l}
7 \text { food group } \\
\text { classification }
\end{array}
\end{array}
$$

\section{No reference}

$$
\begin{array}{ll}
\text { Not judged } & \text { Not judged } \\
\text { Previous 24 hours } & 7 \text { food group } \\
& \text { classification not } \\
\text { fully described }
\end{array}
$$

(Arimond et al.,

$$
\text { 2010) }
$$

$\begin{array}{ll}\text { Not judged } & \text { Not judged } \\ \text { Previous 24 hours } & \begin{array}{l}10 \text { food group } \\ \text { classification }\end{array}\end{array}$
Not judged
Not judged
Previous 24 hours 7 food group
classification

(WHO, 2008)
Not judged

\section{Misleading}

Applied a non-

defined FGI to

individuals as a

measure of

household food

security

Not judged

No use of cut-off

Correct

\section{Not judged}

No use of cut-off

\section{Correct}

\section{Not judged}

No use of cut-off

Misleading

Interpreted a

nutrient-dense FGI

applied to

individuals as a

measure of

household food

security/food

access.

Not judged

No use of cut-off

Correct

But once the

authors presented

the dietary

diversity score of

the children as 
representative for entire household

M'Kaibi et al. Kenya (2017)
Cross-

sectiona

survey
Children 24-59

months of age

$(\mathrm{n}=477)$
Not judged

Unclear how the

authors handled

the 2 different

days in

constructing the

score.
Not judged

Arbitrary cut-of

Correct

of at least 4 of the

9 food groups 